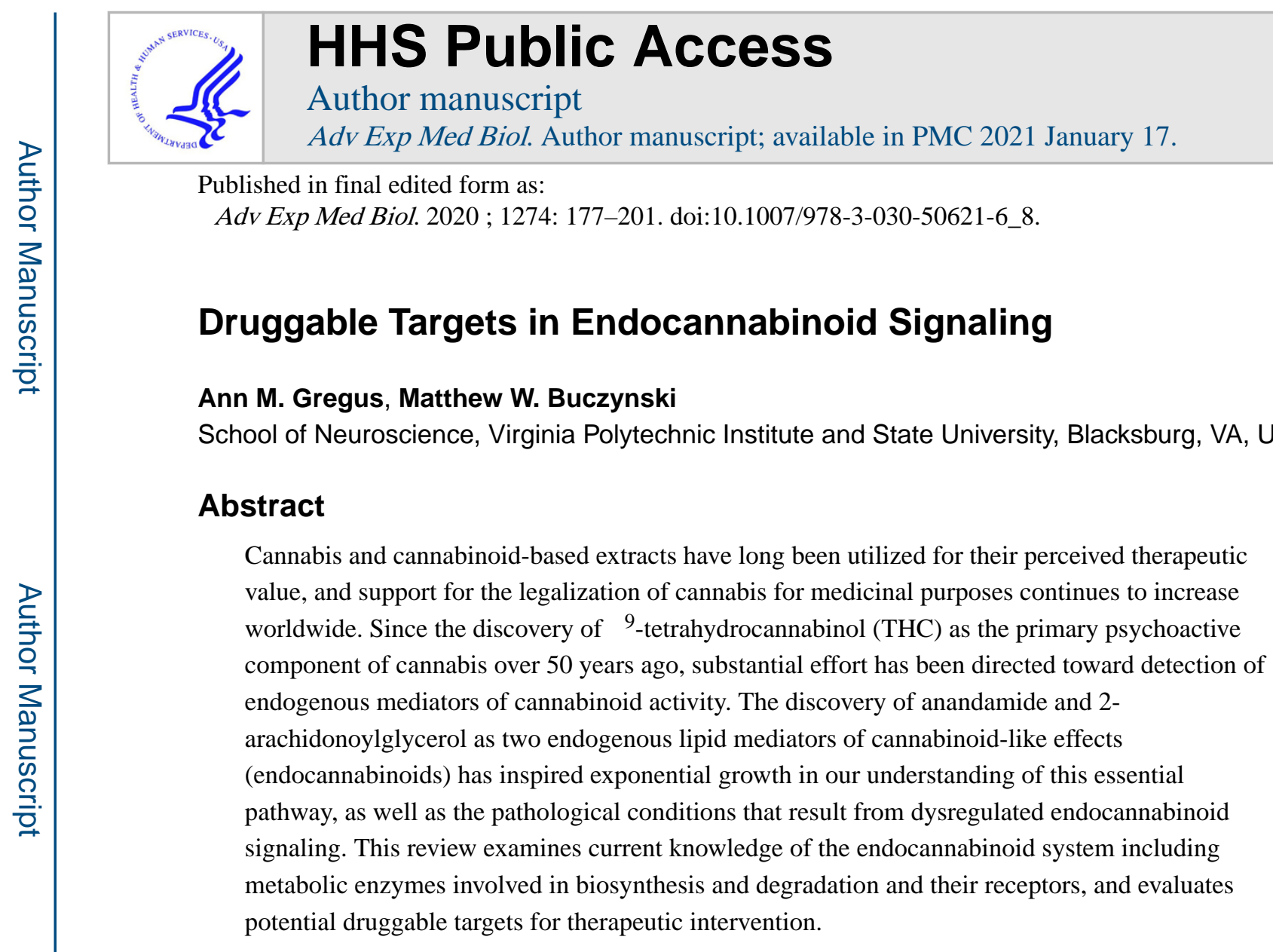

\title{
Keywords
}

Endocannabinoid; GPCR; $\mathrm{CB}_{1} ; \mathrm{CB}_{2} ; \mathrm{FAAH}$

\subsection{Cannabinoids as Therapeutics}

For centuries, cannabis and cannabinoid-based extracts were thought to possess therapeutic value. In recent years, the use of medical marijuana has increased for a wide variety of disorders in the United States, and changes in the legal landscape and public opinion support expanding its recreational availability nationwide. The 2010 , a resolution adopted by the American Medical Association advocated reconsideration of marijuana as a Schedule I controlled substance given the potential therapeutic value of marijuana and cannabis-based products. As of January 1, 2020, 33 states have legalized the sale of medical marijuana, with additional states considering similar legislation with possible enaction in the near future.

The primary psychoactive component of cannabis was identified as $\Delta^{9}$-tetrahydrocannabinol (THC) by Yechiel Gaoni and Raphael Mechoulam in the 1960s [1, 2]. While hundreds of bioactive molecules have been identified in cannabis thus far [3], THC recapitulates many of the pharmacological properties attributed to marijuana in both rodent models and in humans $[4,5]$. Subsequent worldwide efforts were aimed at the discovery of both synthetic and

mwb@vt.edu.

Declaration of Competing Interest

The authors declare that they have no competing interests. 
semi-synthetic cannabinoids capable of producing cannabinoid-like effects in vivo for the eventual development of patentable drugs with verifiable therapeutic value. While many hundreds of cannabinoid compounds were created in subsequent years, the pharmacological properties of these compounds often retained or exacerbated psychoactive effects when compared with THC [6], and thus many of these early cannabinoid-mimetics were not heavily pursued in clinical trials. Alternatively, synthetic cannabinoids began to reemerge as a recreational alternative to traditional cannabis in convenience stores and online marketplaces during the mid-2000s under pseudonyms such as "Spice" and "K2". Synthetic cannabinoids were generally consumed by inhalation via cigarettes containing herbal substances along with these synthetic molecules to obtain euphoric, anxiolytic, and antidepressant-like effects. Whereas traditional cannabis products generally have been considered safe across a wide dose range, numerous case reports illustrate that synthetic cannabinoids produce deleterious effects including paranoia, tachycardia, panic, convulsions, psychosis, visual/auditory hallucinations, vomiting, and seizures [6].

Thus far, two cannabinoid-based therapeutics have obtained FDA approval: Marinol ${ }^{\circledR}$ (dronabinol or THC) and Cesamet ${ }^{\circledR}$ (nabilone), a synthetic cannabinoid [7, 8], for the treatment of chemotherapy-induced nausea and emesis. Marinol also has been indicated as an appetite stimulant to treat cachexia in AIDS patients. A third medication, formulated with equivalent concentrations of THC and cannabidiol (CBD) known as Sativex ${ }^{\circledR}$, has been approved in several countries outside the United States for the relief of spasticity in multiple sclerosis (MS) patients [9]. While the widespread use of medical marijuana suggests potential therapeutic value for a number of diseases, psychoactive effects and addictive potential of cannabinoids with chronic usage may limit widespread use in clinical practice. Additionally, their CNS effects complicate interpretation of efficacy in clinical trials as patients can easily determine whether or not they are receiving the drug or a placebo. Thus, substantial efforts are directed toward evaluating alternative targets in the cannabinoid signaling pathway for the development of safe and effective therapeutics.

\subsection{Selective Modulation of Cannabinoid Receptors}

While significant adverse effects and lack of efficacy have hampered the development of cannabinoid receptor antagonists for clinical use [10-14], these compounds served as important tools for the discovery of endogenous cannabinoid receptors $1\left(\mathrm{CB}_{1}\right)$ and $2\left(\mathrm{CB}_{2}\right)$ and their classification as $\mathrm{G}$ protein-coupled receptors [15]. Binding studies conducted using radiolabeled versions of potent synthetic cannabinoids such as CP-55,940 revealed highaffinity cannabinoid-specific binding sites via radioactive displacement by THC or other synthetic cannabinoids $[16,17]$. Subsequent efforts harnessed these approaches to discover $\mathrm{CB}_{1}[18,19]$ and $\mathrm{CB}_{2}$ receptors [20], respectively. Both $\mathrm{CB}_{1}$ and $\mathrm{CB}_{2}$ receptors couple to $\mathrm{Ga}_{\mathrm{i} / \mathrm{o}}$ proteins to inhibit adenylate cyclase activity and reduce production of cyclic AMP $[21,22]$. While $\mathrm{CB}_{1}$ receptors are enriched in neuronal synapses (where they inhibit neurotransmitter release), $\mathrm{CB}_{2}$ is strongly expressed in immune cells and glia [23-25]. Many of the psychoactive effects of THC and other cannabinoids can be attributed to actions on the $\mathrm{CB}_{1}$ receptor [26], yet mounting evidence paints a more complex picture of the cell-type specific expression patterns of cannabinoid receptors in vivo. 
Following the discovery of endogenously expressed cannabinoid receptors, investigators raced to develop the first potent and selective $\mathrm{CB}_{1}$ and $\mathrm{CB}_{2}$ receptor modulators. From the many compounds identified, SR141716A (rimonabant) represents the most wellcharacterized drug in this class [27]. Subsequently, it was demonstrated that $\mathrm{CB}_{1}$-selective rimonabant blocks acute cannabinoid-induced tetrad behaviors in mice [27], alters dopamine release in rats [28, 29], precipitates withdrawal in THC-dependent rats [30-32], and inhibits long-term potentiation in rodent brain slices [33,34]. It has been shown in multiple preclinical models of nociception that rimonabant exacerbates hyperalgesia [35-37] and attenuates cannabinoid-induced analgesic effects [35, 37] suggesting an opportunity for newer generation therapeutics that modify endocannabinoid signaling in the treatment of chronic pain. Rimonabant approved in 2006 as an anti-obesity medication in Europe (Acomplia, Zimulti), but was later associated with increased incidence of severe adverse psychiatric consequences during Phase III clinical trials to examine its efficacy as an obesity treatment and smoking cessation therapy [38, 39]. As a result, rimonabant did not garner FDA approval in the United States, and was subsequently pulled from the market worldwide in 2008 .

The localization of $\mathrm{CB}_{2}$ primarily in immune cells with limited expression in neurons may underlie its implication in several diseases with an inflammatory component including neurodegenerative and autoimmune diseases [40-42]. While a suite of $\mathrm{CB}_{2}$ agonists have been synthesized to date, a collaborative effort between multiple academic and industry laboratories identified substantial differences in their mechanisms of action, pharmacokinetic properties, and off-target effects in vivo [43]. Based on their collective findings on a wide range of compounds, this research team recommends using HU910, HU308, or JWH133 as potent and in vivo active agonists of the $\mathrm{CB}_{2}$ receptor for subsequent drug discovery efforts of clinically useful $\mathrm{CB}_{2}$-based therapeutics. This endeavor has proven to be more challenging than initially expected, as only a few synthetic $\mathrm{CB}_{2}$ agonists have reached clinical trials (GW842166X, CP-55,940, S-777469, and JTE-907), with none completing phase II for chronic pain indications [42]. Currently, the $\mathrm{CB}_{2}$ agonist JBT-101 is undergoing Phase II testing for efficacy in autoimmune diseases including systemic lupus erythematosus (NCT03093402) and diffuse scleroderma, where it has shown some beneficial effects (NCT02465437).

\subsection{Two Primary Endogenous Cannabinoids: Anandamide and 2- Arachidonoylglycerol}

Nearly 30 years ago, two derivatives of arachidonic acid were identified as the endogenous cannabinoid receptor ligands. Anandamide (AEA) was the first endocannabinoid (eCB) to be discovered [44], closely followed by identification of a second endogenous molecule, 2arachido noylglycerol (2-AG), signaling via $\mathrm{CB}_{1}$ and $\mathrm{CB}_{2}$ receptors [45, 46]. AEA and 2AG retain an arachidonoyl moiety that imparts a significant amount of their bioactivity. While endocannabinoid-related lipids generated from other fatty acids substrates, including palmitoylethanolamide [47] and oleoylethanolamide [48] have described as eCBs, these molecules do not interact with cannabinoid receptors $[49,50]$. Thus, AEA and 2-AG are still viewed as the primary endogenous mediators of cannabinoid signaling. 
Historically, evidence for an eCB mechanism in vivo was determined indirectly using cannabinoid receptor antagonists, without certainty of the identity of the signaling molecule(s). Most studies quantified eCB content primarily by lipid extraction and purification from bulk tissue, followed by subsequent analysis with liquid chromatography coupled with mass spectrometry. Several excellent articles outline this process [51-54].

However, there is significant debate regarding the physiological range of eCB concentrations in various regions, as there is considerable variability in estimates of brain AEA and 2-AG content. Notably, a significant pool of 2-AG serves as an intracellular substrate for triacylglycerol formation in energy metabolism and may not participate in cannabinoid signaling [55]. An alternate approach utilizing in vivo microdialysis samples of interstitial, signaling-competent eCBs from awake, behaving animals with exquisite sensitivity [55, 56]. Using this method, basal interstitial AEA and 2-AG in the brain are estimated at low to midnanomolar levels, physiologically relevant concentrations for activating cannabinoid receptors in vivo [55, 57].

\subsection{Selective Inhibitor Development Using Activity-Based Protein Profiling (ABPP)}

Drug selectivity presented a major challenge in early efforts in the discovery of drug candidates that modulate endocannabinoid metabolism. Initial pharmacology studies suggested that these enzymes were not rate-limiting, and thus near-complete inhibition is required to produce therapeutic effects [58-61]. Moreover, many of these enzymes utilized the same mechanism of action (serine hydrolase), so compounds used at doses needed for complete inhibition were more likely to exhibit off-target effects. Thus, it was particularly challenging to develop inhibitors for the serine hydrolases, a class of over 200 enzymes with a wide range of biological functions [62]. For example, partial inhibition of acetylcholinesterase by donepezil can improve cognitive function in patients with Alzheimer's disease [63]. However, acetylcholinesterase knockout mice typically do not survive to adulthood [64], and complete inhibition by non-selective nerve agents such as Sarin produce lethal neurotoxicity [65]. Given the large number of unannotated serine hydrolases in the human body [62], it is plausible that inhibition of additional off-target serine hydrolases may have similar safety and toxicity issues. Thus, the development of a safe and effective therapeutic targeting endocannabinoid metabolism requires substantial preclinical pharmacokinetic and pharmacodynamic validation prior to entering clinical trials.

The use of activity-based protein profiling (ABPP) approaches has greatly facilitated the development of many of the selective inhibitors currently used in academic research and clinical trials [66]. While non-selective serine hydrolase inhibitors such as organophosphates would raise safety concerns as chronically administered therapeutics, their broad-spectrum capacity to covalently capture a wide range of endogenous serine hydrolases render them an excellent tool for evaluating potency and selectivity of potential drug candidates in vivo. The first broad-spectrum fluorophosphonate probes contained a rhodamine or biotin tag [67], which allowed any serine hydrolases captured by these probes to be visualized by in-gel fluorescence or identified using mass spectrometry. In competition experiments, any serine hydrolase inhibited by a drug would fail to be captured by the fluorophosphonate probe 
under those treatment conditions and the corresponding fluorescence or mass spectra would be diminished. In addition to broad-spectrum probes that capture high abundance serine hydrolases, a number of more selective ABPP probes have been synthesized for discovery of inhibitors for difficult targets, such as diacylglycerol lipases [59, 68-71], with procedural details outlined in several excellent reviews [71, 72]. It follows that potential drug-like molecules can be modified to contain alkyne moieties which have minimal effect on their selectivity but allow their direct targets to then be bound by an azide-functionalized rhodamine or biotin using click chemistry techniques. Collectively, this approach can provide an in vivo readout of both potency and selectivity while significantly facilitating the identification of off-targets for novel inhibitors.

These techniques have been employed to great effect in the development of a selective fatty acid amide hydrolase (FAAH) inhibitor by Pfizer. Systemic delivery of the initial lead compound (PF-3845) exhibits minimal serine hydrolase off-target effects in both brain and liver tissue at doses that abolish FAAH activity [58]. Moreover, an alkyne-functionalized PF-3845 provides direct evidence for the selectivity of this compound, as minimal off-target binding was identified. While minor modifications of the lead compound were made to improve efficacy and reduce interactions with liver cytochrome P450s (CYPs) that cause unwanted drug-drug interactions [73], the final candidate to enter clinical trials (PF-04457845) is based on the chemotype PF-3845, retaining the selectivity profile of the original lead compound [74].

\subsection{Targeting Endocannabinoid Degradation}

Increasing endogenous cannabinoid signaling represents an alternative therapeutic approach to using cannabinoid receptor agonists such as THC. By inhibiting the natural breakdown of endogenous AEA and/or 2-AG, this approach would ideally recapitulate some of the beneficial therapeutic effects of cannabinoids while reducing undesirable side effects. In support of this approach, Long and colleagues used a combination of chemical inhibitors and genetic approaches to show that inhibiting all of the primary endocannabinoid degradative enzymes (FAAH, MGLL, ABHD6) in mice produces similar cannabinoidappropriate responding in a drug discrimination test to THC [75]. Importantly, selective inhibition of either AEA or 2-AG degradation failed to recapitulate THC-like responsivity. This study provides clear support for the therapeutic viability of selective inhibition of specific endocannabinoid pathways with potential for reduced side-effect profile. Accordingly, the following sections will evaluate current clinical and preclinical studies evaluating inhibitors fatty acid amide hydrolase (FAAH), monoacylglycerol lipase (MGLL), and $\alpha / \beta$ hydrolase domain 6 (ABHD6).

\section{Fatty Acid Amide Hydrolase (FAAH)}

Following the discovery of AEA as an endogenous ligand for the $\mathrm{CB}_{1}$ receptor [44], the search began for the enzyme(s) regulating its metabolism. In 1996, the fatty acid amide hydrolase (FAAH) was identified as the primary enzyme responsible for AEA degradation $[76,77]$. Perturbation of FAAH activity via genetic deletion or pharmacological inhibition markedly reduces AEA hydrolysis, thereby elevating AEA levels in multiple organ systems 
in rodents [78]. In addition to AEA, FAAH metabolizes a number of other fatty acid amide substrates such as oleoylethanolamine and palmitoylethanoamine $[58,73]$, resulting in a battery of $\mathrm{CB}_{1}$-dependent and $\mathrm{CB}_{1}$-independent behavioral changes in rodents. These effects include, but are not limited to, decreased anxiety-like [79-81] and depression-like behaviors [82, 83], gastrointestinal function [84-88], altered expression of drug and alcohol withdrawal [89-93], as well as diminished inflammatory and neuropathic pain states [74, 94-97]. This substantial body of preclinical evidence inspired clinical development of FAAH inhibitors by several pharmaceutical companies including PF-04457845 (Pfizer), JNJ-42165279 (Janssen), ASP3652 (Astellas), V158866 (Vernalis) and BIA 10-2474 (Bial). Likewise, FAAH inhibitors have been evaluated for treatment of several disease indications, including cannabis use disorder [98], fear memory extinction [99], Tourette Syndrome (NCT02134080 - terminated for lack of funding), chronic pain due to spinal cord injury (NCT01748695), osteoarthritis [100], and prostatitis [101].

The most notable failure in FAAH drug development to date is BIA 10-2474, a potent and long-acting CNS-active inhibitor of FAAH which produced acute neurotoxicity in 5 patients, one of which resulted in death in the multiple ascending dose part of the study in Phase I [102]. The expression of severe adverse events had not yet been observed at such a late stage of a first-in-human study [103]. It was later revealed that BIA 10-2474 inhibits several lipases that are not targeted by PF04457845, and produces substantial changes in lipid networks in human cortical neurons that may lead to metabolic dysregulation [104]. One of these off-targets is Aldehyde Dehydrogenase 2, which has been implicated in neuroprotection from oxidative stress-related damage [105]. While BIAL has since conducted a series of toxicity studies in animals [106], in-depth analysis of the trial PK/PD parameters and study periods may help determine conclusively the drug and metabolite concentrations underlying these adverse events.

In contrast to BIA 10-2474, most clinical candidates were generally safe and well-tolerated [101, 107-109], and some report efficacy of FAAH inhibition in primary outcome measurements for reducing stress reactivity [99] and cannabis withdrawal symptoms [98]. However, PF-04457845 and ASP3652 failed to attenuate osteoarthritis or prostatitis pain, respectively $[101,110]$ despite considerable data demonstrating antihyperalgesic effects of FAAH inhibition in several preclinical models of chronic pain states. It has been hypothesized that premature termination of the osteoarthritis study due to lack of efficacy, while necessary, may have prevented the adequate assessment of contribution of nonresponders and placebo effects [110]. Furthermore, the human trial focused on assessment of affective measures of pain that generally were not evaluated in rodent models, with exception of one study reporting no effect of FAAH inhibition on osteoarthritis-induced burrowing behavior [111]. Thus, it may be advantageous to include spontaneous and functional output measures of pain-like behaviors (e.g., locomotor activity, grip force, nesting, sucrose preference) in preclinical studies in order to help inform selection of disease indication for clinical trials. 


\section{Monoacylglycerol Lipase (MGLL)}

The discovery of 2-AG as a bonafide endocannabinoid led to the search for enzymes regulating its metabolism in vivo. While FAAH was briefly considered a potential candidate, both chemical and genetic inhibition of FAAH failed to substantially elevate 2-AG compared with AEA. Monoacylglycerol lipase was identified as the primary metabolic driver of cannabinergic 2-AG breakdown [112, 113], and genetic deletion of MGLL in mice confirmed these findings [114]. Genetic and pharmacological analyses demonstrate ubiquitous expression of MGLL across most tissues including brain, liver, kidney, lung, heart, muscle, intestines, and adipose tissue $[60,115,116]$. These mice exhibited decreased body weight as adults, hastened increased latency to inflammatory thermal hyperalgesia, and alterations in basal pain sensitivity [117]. Genetic inactivation of MGLL enhanced extinction and reversal learning [118] and facilitates anxiety-like behavior [119], neurophysiological analyses reveals cannabinoid-dependent changes in excitatory and inhibitor synaptic plasticity in multiple brain regions in mice [119-121]. Accordingly, selective chemical inhibitors would be necessary to distinguish between role of 2-AG signaling in adults with the critical role of this pathway in neuronal development.

The early chemical inhibitors developed in academic labs suggested a prominent role for MGLL in 2-AG metabolism and neuronal signaling [122-127]. The first ABPP-validated selective murine MGLL inhibitor JZL-184 confirmed many of these findings, including enhancement of depolarization-induced 2-AG release and reduction of cannabinoid-sensitive pain states [128]. The development of JZL-184 greatly accelerated the evaluation of the molecular and behavioral role of MGLL in mice, with over 200 publications using this compound to date. A number of potential physiological roles have been discovered using JZL-184 including, but not limited to, drug withdrawal [91, 129, 130], pain states [131133], stress [134, 135], immune function [136-138], cancer [139-141], gastrointestinal function [137, 142, 143], and neurodegeneration [144-147]. Importantly, chronic administration of JZL-184 produces $\mathrm{CB}_{1}$ receptor desensitization and functional antagonism [148], suggesting that pharmacological tolerance of an MGLL inhibitor may produce a therapeutic profile more similar to a $\mathrm{CB}_{1}$ antagonist than with cannabinoid-based therapeutics such as THC. However, limitations in JZL-184 pharmacology including partial inhibition of ABHD6 and FAAH during chronic dosing procedures [149] and limited efficacy in rats [60] have helped open the door for next-generation compounds that address these concerns [149-152]. Thus, future studies should validate the pharmacological selectivity of these compounds and dosing procedures for proper interpretation of results.

Recently, Abide Therapeutics discovered ABX-1431 (acquired by Lundbeck, and rebranded as Lu AG06466) as the potent first-in-class, orally bioavailable and selective inhibitor of MGLL, now under development for as a therapeutic for movement disorders, neurodegenerative diseases and pain [153]. A Phase I Experimental Hyperalgesia study of ABX-1431 may yield insight into its viability in this therapeutic space (NCT02929264), as this model is generally highly predictive of clinical success for Neuropathic Pain [154]. At present, this molecule is undergoing a Phase IIa trial for the treatment of Tourette syndrome (NCT03625453) and a Phase I trial for neuropathic pain (NCT03138421). Likewise, Pfizer has developed a selective covalent MGLL inhibitor [155] and a corresponding ${ }^{11} \mathrm{C}$-PET 
tracer [156] for evaluating the pharmacokinetics of this compound as part of a Phase 1 clinical trial (NCT03100136). Additionally, both Takeda Pharmaceutical Co. [157] and Janssen Research [158] recently have developed non-covalent MGLL inhibitors that show preclinical viability for target engagement and increased 2-AG levels in CNS and peripheral tissue, but these candidates have not yet entered clinical trials.

\section{a/ $\beta$ Hydrolase Domain 6 (ABHD6)}

While MGLL drives the majority of 2-AG breakdown in vivo, emerging evidence suggests that other enzymes play a supportive role in this process. Initial studies using immortalized BV-2 microglial cells, which do not express MGLL, provide clear evidence of alternative 2AG metabolism pathways [159]. While compensation by FAAH accounted for about half of the 2-AG metabolism, the use of selective inhibitors revealed that the remaining activity could be attributed to unknown enzyme(s). Using a functional proteomic approach, two additional serine hydrolases (ABHD6 and ABHD12) were identified as potential 2-AG metabolic enzymes [160]. Ultimately, the unknown 2-AG activity in BV-2 microglia was attributed to ABHD6, which regulates endocannabinergic signals to alter excitatory [161] and inhibitory [162] synapses in the brain.

Our understanding of the significance of ABHD6 in regulating endocannabinoid signaling and other lipid pathways has emerged from studies of targeted inactivation using genetic and chemical tools [163]. Constitutive deletion of ABHD6 reveals its critical role in energy metabolism [164, 165] but not in lysosomal storage disorders [166]. ABHD6 knockout mice are protected from high-fat diet-induced obesity [164] and displayed increased decreased body weight, increased energy expenditure, improved glucose tolerance and insulin sensitivity, and changes in white and brown adipose tissue composition [165]. Many of these metabolic effects can be recapitulated by antisense oligonucleotides or treatment with WWL70, the first chemical inhibitor designed to target ABHD6. Early studies using WWL70 implicate ABHD6 function in traumatic brain injury [167], obesity and type II diabetes [165, 168], seizure activity [169, 170], inflammation and pain [171, 172]. Selective blockade of ABHD6 with the newer generation peripherally-restricted inhibitor KT-203 decreases pancreatic cancer cell metastasis [173], while KT-182 modestly attenuates autoimmune demyelination [174, 175], in contrast with a previous study reporting significant reduction of clinical signs in the experimental autoimmune encephalitis model of Multiple Sclerosis with WWL70 [176]. At present, it is not clear if ABHD6 drives metabolic changes by enzymatic regulation of 2-AG signaling [177] or other lipid pathways [164].

Since ABHD6 exhibits promiscuity in its acceptance of lipid substrates [164], the process of determining the specific lipid mediators responsible for its effects presents a substantial challenge. Thus, studies utilizing inhibitors with off-target effects should be interpreted with caution for future drug development efforts.

\section{a/ $\beta$ Hydrolase Domain 12 (ABHD12)}

Since its discovery as a serine hydrolase with in vitro 2-AG metabolic activity [160], the physiological role of ABHD12 has remained poorly understood. Loss-of-function mutations in ABHD12 cause the rare neurodegenerative disorder PHARC (polyneuropathy, hearing loss, retinosis pigmentosa, and cataract) in humans [178-182], which is phenocopied in 
ABHD12 knockout mice [178]. While ABHD12 knockout mice have increased levels of 2AG in multiple brain regions [183], the primary function of this enzyme in vivo is likely a lysophosphatidylserine lipase. Indeed, both genetic deletion $[178,184]$ and selective inhibition [184, 185] of ABHD12 generate substantially elevated levels of very long chain lysophosphatidylserine levels in vivo [186]. ABHD12 and downstream target lysophosphatidylserine receptors are coexpressed in glia and in immune cells, and treatment of macrophages with the selective ABHD12 inhibitor DO264 exacerbated immune responsivity [178, 184, 187]. Although acute chemical inactivation of ABHD12 did not produce the severe behavioral deficits found in knockout mice [184, 187], it is presently unclear if the PHARC phenotype would emerge following chronic, long-term drug treatment. Given its restricted contribution to endocannabinoid signaling and potential role in neuroprotection, ABHD12 may offer limited opportunity for therapeutic development when compared with other targets in the endocannabinoid metabolic pathway.

\subsection{Targeting Endocannabinoid Biosynthesis}

Due to concerns regarding safety and tolerability with cannabinoid receptor antagonism, efforts have emerged to selectively decrease cannabinoid signaling as an alternative therapeutic approach. While $\mathrm{CB}_{1}$ receptor antagonists or inverse agonists such as rimonabant and taranabant demonstrated efficacy in the treatment of obesity, type II diabetes and nicotine dependence [188-192], serious adverse psychiatric consequences significantly limit clinical utility [10-14], ultimately precluding their approval by the FDA. Instead, by inhibiting the natural production of endogenous AEA and/or 2-AG, targeting endocannabinoid biosynthesis might recapitulate some of the beneficial therapeutic effects of receptor antagonists while mitigating undesirable side effects.

The FDA-approved drug Orlistat (tetrahydrolipstatin, sold over-the-counter as Alli ${ }^{\circledR}$ ) indicated for the treatment of obesity was designed as a pancreatic and gastric lipase inhibitor [193, 194], but nonetheless has a number of potential off-target effects including inhibition of the two diacylglycerol lipases a (DAGLa) and $\beta$ (DAGL $\beta$ ) that generate 2-AG in vivo. Unlike rimonabant, Orlistat does not produce serious psychiatric events, suggesting that inhibition of endocannabinoid biosynthesis may represent a viable alternative to $\mathrm{CB}_{1}$ receptor antagonists. While the study of endocannabinoid biosynthetic pathways and the subsequent discovery of corresponding selective chemical inhibitors is in its nascent stage, a number of recent advances have bolstered this field and may yield unique candidates for future drug development. Several selective ABPP probes have been developed to facilitate inhibitor development against DAGLs and other potential endocannabinoid biosynthases, including some based on the tetrahydrolipstatin structure [195]. Accordingly, the following sections will evaluate current clinical and preclinical studies evaluating inhibitors of DAGLa and $\beta$ (DAGL $\beta$, n-acyl phosphatidylethanolamine phospholipase D (NAPE-PLD), and other enzymes involved in endocannabinoid biosynthesis.

\section{Diacylglycerol Lipase a (DAGLa)}

The endogenous biosynthesis of signaling competent $2-A G$ is driven by the enzymes diacylglycerol lipase a (DAGLa) and diacylglycerol lipase $\beta$ (DAGL $\beta$ ). While both of these 
serine hydrolases convert diacylglycerol into 2-AG, they exhibit unique cellular and tissue specific expression. Specifically, DAGLa is predominantly expressed in neuronal tissue [196] and DAGLa knockout mice exhibit approximately $80 \%$ lower levels of 2-AG in the brain and spinal cord, compared with a $50 \%$ reduction of $2-\mathrm{AG}$ in liver and adipose tissue [197, 198]. Within the central nervous system, neurons contain the predominant amount of DAGLa as compared with glial cells [196, 199-201]. In addition, many of the metabolic and behavioral phenotypes found in $\mathrm{CB}_{1}$ receptor knockout mice are recapitulated by genetic deletion of DAGLa. Mice with genetic inactivation of either $\mathrm{CB}_{1}$ or DAGLa both exhibit signs of enhanced metabolic function including lower body weight and decreased body fat, as well as reduced fasting insulin release and blood lipid levels [197, 202].

However, both genotypes also showed signs of psychiatric dysfunction including less marble-burying and shorter latencies in the forced swim test [202-204]. DAGLa mice also exhibited increased mortality beginning around 8-10 weeks of age [202]. Mounting evidence indicates that DAGLa plays a critical role in neuronal developmental processes [205-210], suggesting that psychiatric behavioral phenotypes may results from neurodevelopmental deficiencies as opposed to the direct signaling actions of DAGLa. Collectively, these findings highlight the necessity for rigorous behavioral evaluation of a selective DAGLa inhibitor prior to initiation of clinical development.

Early DAGLa inhibitors such as tetrahydrolipstatin were utilized mainly in electrophysiological studies, yet the recent development of in vivo-active diacylglycerol lipase inhibitors has offered important insight into the consequences of global chemical inactivation of these enzymes [211]. Ogasawara and colleagues created a suite of CNSactive covalent inhibitors of diacylglycerol lipases, most notably DO34 and DH376 [61]. Compared with DH376, DO34 exhibits enhanced selectivity for DAGLa, however both compounds block DAGLa and DAGL $\beta$ following systemic administration and are bloodbrain barrier permeable. Despite their off-target effects, each molecule targets a unique group of serine hydrolases. Importantly, DO53 blocks all spurious targets of DO34 while sparing DAGLa and DAGL $\beta$, thus serving as a critical negative control compound for in vivo pharmacology studies. Furthermore, Baggelaar et al. report LEI105 as a reversible inhibitor of diacylglycerol lipases, with potent inactivation of DAGLa and DAGL $\beta$ and minimal cross-reactivity with other endocannabinoid metabolic enzymes in mice [69]. Surprisingly, intracerebroventricular administration in rats of the DAGL $\beta$ inhibitor KT172 (originally validated in mice) actually reduces activity of DAGLa $(\sim 80 \%)$ and DAGL $\beta$ $(\sim 50 \%)$ in the brain [162], suggesting this approach as a potential alternative to rimonabant antagonism of $\mathrm{CB}_{1}$ for smoking cessation. While the selectivity of these compounds generally has been evaluated against the human and mouse orthologs, there is precedent for species-specific selectivity when targeting enzymes in the eCB pathway [60]. Thus, optimization is needed in order to fully validate effects of these compounds in rats for behavioral studies and in multiple species for future clinical development.

\section{Diacylglycerol Lipase $\beta$ (DAGL $\beta$ )}

With the initial cloning in 2003 of DAGLa and DAGL $\beta$ [196], it was demonstrated that DAGL expression pattern shifts from axonal tracts to dendritic fields, consistent with later reports that DAGL activity is required for synaptic plasticity [125, 126, 212, 213], axonal 
growth and guidance [214], adult neurogenesis [215, 216] and oligodendrocyte differentiation [217]. Several studies suggest that while DAGLa is the predominant 2-AG synthesizing enzyme for endocannabinoid-mediated modulation of neurotransmission in adults [197, 198, 218], DAGL $\beta$ is more abundantly expressed in the developing CNS [196, 219]. DAGL $\beta$ contributes to depolarization-induced suppression of excitation in early postnatal hippocampal autaptic neurons [209] and neurite outgrowth in culture models [208]. Outside of the CNS, DAGL $\beta$ is widely expressed in multiple sites including white blood cells [220], liver [197] and adipose tissue [221], where it may be correlated with serum highdensity lipoprotein cholesterol levels. Most notably, while LPS-induced eCB-eicosanoid crosstalk is dependent on DAGL $\beta$ in microglia [201], macrophages [59] and dendritic cells [222]. These observations indicate a crucial role for DAGL $\beta$ in immune function and inflammation, consistent with the implication of this enzyme in pathologies associated with alcoholic fatty liver disease [223], Alzheimer's disease [224] as well as inflammatory, neuropathic and post-surgical pain [225-227].

The development of in vivo-active DAGL $\beta$ inhibitors has facilitated significantly our understanding of the role of this enzyme. Systemic administration of currently available blood-brain barrier-permeable DAGL $\beta$ inhibitors exhibit cross-reactivity with both DAGLa and DAGL $\beta$ [211], however Hsu and colleagues have developed peripherally-restricted inhibitors KT109 and KT172, which exhibit $~ 60$-fold selectivity for DAGL $\beta$ versus DAGLa in mice [59]. To account for its limited off-target effects on ABHD6 and to determine DAGL $\beta$-specific biology, the negative control compound KT195 was utilized as a selective ABHD6 inhibitor. Acute treatment with KT109 or KT172 reveals a role for DAGL $\beta$ in 2-AG metabolism, as well as in downstream eicosanoid production and inflammatory signaling in peripheral macrophages [59]. Delivery of liposome-encapsulated KT109 produces macrophage-specific targeted inhibition of DAGL $\beta$, with no apparent activity of other tissues in vivo [228]. This mode of administration substantially enhances anti-nociceptive potency of KT109 compared with traditional systemic treatment, thereby demonstrating potential for DAGL $\beta$ as a novel druggable target with potential indications in inflammatory diseases.

\section{N-Acyl Phosphatidylethanolamine Phospholipase D (NAPE-PLD)}

While multiple enzymatic pathways have been implicated in the endogenous biosynthesis of AEA, none has been definitively nominated as the "AEA synthase" to date. The initial evaluation of n-acyl phosphatidylethanolamine phospholipase D (NAPE-PLD) as a zinc hydrolase capable of producing $n$-acylethanolamines (including AEA) offered the first example of a potential anandamide synthase [229]. Consistent with this purported role of NAPE-PLD in vivo, overexpression of this enzyme in mammalian culture systems increases AEA and other n-acylethanolamines [230]. However, while NAPE-PLD knockout mice express lower levels of saturated and mono-unsaturated n-acylethanolamines, reduction of AEA is inconsistent between reports [231-233].

Recent studies utilizing global and spatio-temporal genetic inactivation of NAPE-PLD have attempted to elucidate the physiological role of this enzyme. Mice expressing a constitutive knockout of NAPE-PLD exhibit no changes in body mass composition or glucose tolerance 
on a normal chow diet, yet inactivation of NAPE-PLD selectively in either adipose [234] or intestinal tissue [235] leads to an exaggerated obese phenotype on a high-fat diet. Spatiotemporal deletion of NAPE-PLD produces significant decreases in AEA and other nacylethanolamines in the targeted tissues and alters the composition of gut microbiota in these animals [234, 235]. NAPE-PLD may limit development of obesity through noncannabinergic pathways, as other n-acylethanolamines such as oleoylethanolamine produce robust anorexic effects [48] through multiple receptors including GPR119 [236] and PPARa [237]. However, it should be noted that given the potential for compensatory lipid metabolic pathways in constitutive knockout models, selective chemical inhibitors are critical in order to clarify the function of NAPE-PLD in activity-dependent AEA signaling. Unfortunately, potent CNS-active inhibitors are currently not available as existing compounds lack the necessary pharmacological properties to inhibit NAPE-PLD in vivo [230, 238, 239]. Future work will evaluate if these metabolic changes can be recapitulated and treated using pharmacological tools and subsequently translated into a potential therapeutic for obesity.

\section{Other Potential Anandamide Biosynthetic Enzymes}

In addition to NAPE-PLD, multiple enzymatic pathways leading to the biosynthesis of nacylethanolamines, a family of lipid species that includes AEA, have been discovered. However, current evidence highlights several obstacles to therapeutic drug discovery in this arena. For example, the serine hydrolase ABHD4 can act in concert with glycerophosphodiesterase GDE1 to produce anandamide and other n-acylethanolamines in vitro [240], however levels of AEA in brain tissue are unaltered in GDE1 knockout mice [241]. Likewise, ABHD4 regulates multiple lipid classes, and genetic inactivation of this enzyme elicits comparatively greater changes in lysophosphatidylserine levels [242]. An additional pathway for AEA production utilizing sequential activity of phospholipase $\mathrm{C}$ and tyrosine phosphatases such as lymphoid-specific tyrosine phosphatase (PTPN22) was discovered in macrophages [243, 244]. However, targeting either phospholipases C or PTPN22 alone is expected to exert substantial non-cannabinergic effects, as these enzymes are broadly involved in lipid metabolism and in responsiveness of B and T cells, respectively. Collectively, research on AEA biosynthesis suggests that multiple redundant pathways likely exist in vivo [241, 244], as illustrated by biological compensation when one of these enzymes is inactivated. It follows that the physiological source(s) of AEA and thus the therapeutic utility of inhibitors for these enzymes remain to be fully elucidated.

\subsection{The Interaction Between Endocannabinoids and Eicosanoid Production}

\section{Precursors for Eicosanoid Production}

The primary focus of research on endocannabinoid metabolism centers on changes in 2-AG signaling via cannabinoid receptors. However, recent work has uncovered an important role for prostaglandins and other arachidonic acid metabolites that are derived from endocannabinoid precursors. Although it was previously thought that prostaglandins arise mainly from actions of cytosolic phospholipase $\mathrm{A}_{2}$, genetic inactivation of this enzyme exerts only minimal effect on arachidonic acid levels in the brain [245]. Instead, metabolic 
breakdown of 2-AG by MGLL supplies arachidonic acid for production of proinflammatory prostaglandins by cyclooxygenases during neuroinflammation [138]. Both genetic and chemical inactivation of MGLL attenuate lipopolysaccharide-induced cytokine release and protect against neurodegeneration of dopamine neurons through a $\mathrm{CB}_{1}$-independent mechanism of reduced prostaglandin synthesis. Accordingly, MGLL activity liberates prostaglandins in the brain to facilitate neurodegeneration in mouse models of Alzheimer's disease [246-248], while deletion or pharmacological inhibition of MGLL facilitates cannabinoid receptor-independent blunting of disease progression [246]. MGLL-dependent prostaglandins also mediate the fever response in mice, as genetic or pharmacological inactivation of MGLL blunts LPS-induced elevations in body temperature without altering core body temperature in control mice [249, 250].

Upstream of MGLL, DAGLa and DAGL $\beta$ both contribute to release of arachidonic acid $[197,201]$ and subsequent production of prostaglandins [201], with a prominent role of DAGLa in the brain $[59,197,201]$ and DAGL $\beta$ in microglia and other immune cells [59, 201], respectively. For example, inhibition of DAGL $\beta$ following injury decreases local $\mathrm{PGE}_{2}$ production and attenuates chronic pain-like behaviors in mouse models of neuropathic and inflammatory pain [225]. Furthermore, targeted delivery of the DAGL $\beta$ inhibitor KT-109 using liposomes produces $80 \%$ inactivation in macrophages without altering activity in other tissues such as brain and heart, and reduces LPS-induced allodynia [228], thus providing more direct evidence for peripheral immune DAGL $\beta$ in the inflammatory response.

Alternatively, pharmacological or genetic inactivation of DAGLa abrogates production of prostaglandins in brain tissue, blocks central LPS-induced prostaglandin release and blunts the fever response in these mice [225]. While the role of eCBs in prostaglandin signaling has become clear, our understanding of their contribution(s) to other eicosanoid pathways remains limited, and future studies will establish potential links with lipoxygenases and cytochrome P450s.

\section{Eicosanoid-Like 2-AG Metabolites}

Endocannabinoids also may interact directly with cyclooxygenases as substrates to produce prostaglandin-like compounds with unique biological effects [251]. While the (S)enantiomers of nonsteroidal anti-inflammatory drugs $\left(\right.$ NSAID $\left._{S}\right)$ such as ibuprofen and naproxen inhibit cyclooxygenase to prevent the formation of proinflammatory prostaglandins [252], the (R)-enantiomers of these compounds accomplish only minimal inhibition of enzymatic activity against arachidonic acid substrate. However, (R)-NSAIDs attenuate cyclooxygenase-dependent activity with AEA and 2-AG, thereby acting as potent substrate-selective inhibitors of this class of lipid signals [253]. Importantly, (R)-NSAIDS exhibit antihyperalgesic activity in models of neuropathic pain that is superior to that of traditionally prescribed (S)-NSAID $[254,255]$. Furthermore, levels of endogenous prostaglandin $E_{2}$ glycerol ester are elevated in the carrageenan model of inflammatory pain, contributing to thermal hyperalgesia that is not fully reversed by prostaglandin receptor antagonists [256]. Accordingly, prostaglandin $\mathrm{E}_{2}$ glycerol ester functions as an agonist for the g-protein coupled receptor $\mathrm{P}_{2} \mathrm{Y}_{6}$, with almost four orders of magnitude more potency than the prototypical agonist uridine diphosphate [257]. In a model of colon inflammation, prostaglandin $\mathrm{D}_{2}$ glycerol ester derived from 2-AG, but not related metabolites arising from 
arachidonic acid or AEA, reduced dextran sulfate sodium-induced colitis in mice and are blocked by antagonists of traditional prostaglandin receptors, $\mathrm{DP}_{1}$ and PPARy [258].

\section{Eicosanoid-Like Anandamide Metabolites}

While serving only a limited role in colon inflammation, prostaglandin $\mathrm{D}_{2}$ ethanolamine induces skin cancer apoptosis independent of the putative DP receptors, but the precise mechanism remains unclear [259]. Perhaps the most well-established endogenous prostamide, prostaglandin $\mathrm{F}_{2} \mathrm{a}$ ethanolamine exerts minimal activity through the prostaglandin $\mathrm{F}_{2 a}$ receptor and instead likely acts through an FP receptor variant [260]. A structural analogue of prostaglandin $\mathrm{F}_{2 a}$ ethanolamine, Bimatoprost is an FDA-approved drug marketed under the name Lumigan ${ }^{\circledR}$ (Allergan) for reducing intraocular pressure as a treatment for glaucoma [261], and a sustained-release formulation of Bimatoprost is currently undergoing testing in Phase I/II clinical trials [262]. Patients reported longer and fuller eyelashes during administration of Bimatoprost, so the drug was repurposed as Latisse $^{\circledR}$ and received FDA approval for the treatment of eyelash hypotrichosis [263] In contrast, an antagonist of the prostamide $\mathrm{F}_{2 \mathrm{a}}$ receptor AGN211336 reduces inflammatory pain in mice [264]. Substrate-selective inhibitors affect a number of different pathologies in mice including stress and anxiety-like behaviors (23912944), and future research likely will uncover additional biological roles for these lipids as signaling molecules.

While it has become clear that cyclooxygenases utilize 2-AG and AEA as substrates, research investigating the biological activity of corresponding lipoxygenase and cytochrome P450 enzymes on these lipid species is limited [251] and future studies will help clarify their role(s) in endocannabinoid biology. Collectively, these results suggest a number of novel potential therapeutic avenues for endocannabinoid metabolism inhibitors.

\subsection{Conclusions and Future Directions}

Considerable efforts have been concentrated on targeting endocannabinoid biosynthetic and degradative enzymes as alternatives to $\mathrm{CB}_{1}$-receptor-based therapeutics that can produce serious adverse effects associated with a number of failures in clinical trials. In general, potent and selective inhibitors of FAAH or MGLL that are devoid of off-target effects have demonstrated safety and tolerability in human volunteers. These drug candidates could be met with success in the treatment of neurological diseases and pain if caution is exercised in interpreting preclinical data as well as selection of clinical indication and output measures. Small molecule inhibitors of other eCB enzymes remain in the preclinical discovery stage, but current research suggests some potential druggable targets. DAGLa serves an important physiological role in metabolism and brain function, yet its temporal inhibition may improve smoking cessation. Chemical inactivation of DAGL $\beta$ by liposome-mediated delivery of a peripherally-restricted inhibitor reduces inflammation and pain-like behaviors in mice. DAGL inhibitors undoubtedly will benefit from further chemical optimization in order to improve both selectivity and brain-barrier permeability for CNS indications. In addition, future studies elucidating pathways of anandamide synthesis and exploring substrate-specific inhibitors of cyclooxygenases, lipoxygenases and cytochrome P450s may yield additional promising targets for drug discovery in the cannabinoid therapeutic space. 


\section{Acknowledgements}

This work was supported by the National Institute on Drug Abuse (MWB, R00-DA03586) and National Institute of Arthritis and Musculoskeletal and Skin Diseases (AMG, R01-AR075241).

\section{References}

1. Mechoulam R, Gaoni Y (1965) A total synthesis of Dl-Delta-1-tetrahydrocannabinol, the active constituent of hashish. J Am Chem Soc 87:3273-3275 [PubMed: 14324315]

2. Pertwee RG (2006) Cannabinoid pharmacology: the first 66 years. Br J Pharmacol 147(Suppl 1):S163-S171 [PubMed: 16402100]

3. Mechoulam R (2005) Plant cannabinoids: a neglected pharmacological treasure trove. Br J Pharmacol 146:913-915 [PubMed: 16205721]

4. Perez-Reyes M, Timmons MC, Lipton MA, Davis KH, Wall ME (1972) Intravenous injection in man of 9 -tetrahydrocannabinol and 11-OH- 9 -tetrahydrocannabinol. Science 177:633-635 [PubMed: 4558903]

5. Little PJ, Compton DR, Johnson MR, Melvin LS, Martin BR (1988) Pharmacology and stereoselectivity of structurally novel cannabinoids in mice. J Pharmacol Exp Ther 247:1046-1051 [PubMed: 2849657]

6. Miliano C, Serpelloni G, Rimondo C, Mereu M, Marti M, De Luca MA (2016) Neuropharmacology of new psychoactive substances (NPS): focus on the rewarding and reinforcing properties of cannabimimetics and amphetamine-like stimulants. Front Neurosci 10:153 [PubMed: 27147945]

7. Pertwee RG (2009) Emerging strategies for exploiting cannabinoid receptor agonists as medicines. Br J Pharmacol 156:397-411 [PubMed: 19226257]

8. Rahn EJ, Hohmann AG (2009) Cannabinoids as pharmacotherapies for neuropathic pain: from the bench to the bedside. Neurotherapeutics 6:713-737 [PubMed: 19789075]

9. Syed YY, McKeage K, Scott LJ (2014) Delta-9-tetrahydrocannabinol/cannabidiol (Sativex(R)): a review of its use in patients with moderate to severe spasticity due to multiple sclerosis. Drugs 74:563-578 [PubMed: 24671907]

10. Horder J, Browning M, Di Simplicio M, Cowen PJ, Harmer CJ (2012) Effects of 7 days of treatment with the cannabinoid type 1 receptor antagonist, rimonabant, on emotional processing. $\mathrm{J}$ Psychopharmacol 26:125-132 [PubMed: 21406493]

11. Horder J, Cowen PJ, Di Simplicio M, Browning M, Harmer CJ (2009) Acute administration of the cannabinoid CB1 antagonist rimonabant impairs positive affective memory in healthy volunteers. Psychopharmacology 205:85-91 [PubMed: 19337726]

12. Kipnes MS, Hollander P, Fujioka K, Gantz I, Seck T, Erondu N, Shentu Y, Lu K, Suryawanshi S, Chou M, Johnson-Levonas AO, Heymsfield SB, Shapiro D, Kaufman KD, Amatruda JM (2010) A one-year study to assess the safety and efficacy of the CB1R inverse agonist taranabant in overweight and obese patients with type 2 diabetes. Diabetes Obes Metab 12:517-531 [PubMed: 20518807]

13. Morrison MF, Ceesay P, Gantz I, Kaufman KD, Lines CR (2010) Randomized, controlled, doubleblind trial of taranabant for smoking cessation. Psychopharmacology 209:245-253 [PubMed: 20191360]

14. Wadden TA, Fujioka K, Toubro S, Gantz I, Erondu NE, Chen M, Suryawanshi S, Carofano W, Johnson-Levonas AO, Shapiro DR, Kaufman KD, Heymsfield SB, Amatruda JM (2010) A randomized trial of lifestyle modification and taranabant for maintaining weight loss achieved with a low-calorie diet. Obesity (Silver Spring) 18:2301-2310 [PubMed: 20379151]

15. Pertwee RG (1997) Pharmacology of cannabinoid CB1 and CB2 receptors. Pharmacol Ther 74:129-180 [PubMed: 9336020]

16. Devane WA, Dysarz FA 3rd, Johnson MR, Melvin LS, Howlett AC (1988) Determination and characterization of a cannabinoid receptor in rat brain. Mol Pharmacol 34:605-613 [PubMed: 2848184] 
17. Herkenham M, Lynn AB, Little MD, Johnson MR, Melvin LS, de Costa BR, Rice KC (1990) Cannabinoid receptor localization in brain. Proc Natl Acad Sci U S A 87:1932-1936 [PubMed: 2308954]

18. Gerard CM, Mollereau C, Vassart G, Parmentier M (1991) Molecular cloning of a human cannabinoid receptor which is also expressed in testis. Biochem J 279(Pt 1):129-134 [PubMed: 1718258]

19. Matsuda LA, Lolait SJ, Brownstein MJ, Young AC, Bonner TI (1990) Structure of a cannabinoid receptor and functional expression of the cloned cDNA. Nature 346:561-564 [PubMed: 2165569]

20. Munro S, Thomas KL, Abu-Shaar M (1993) Molecular characterization of a peripheral receptor for cannabinoids. Nature 365:61-65 [PubMed: 7689702]

21. Bayewitch M, Avidor-Reiss T, Levy R, Barg J, Mechoulam R, Vogel Z (1995) The peripheral cannabinoid receptor: adenylate cyclase inhibition and G protein coupling. FEBS Lett 375:143147 [PubMed: 7498464]

22. Felder CC, Briley EM, Axelrod J, Simpson JT, Mackie K, Devane WA (1993) Anandamide, an endogenous cannabimimetic eicosanoid, binds to the cloned human cannabinoid receptor and stimulates receptor-mediated signal transduction. Proc Natl Acad Sci U S A 90:7656-7660 [PubMed: 8395053]

23. Matsuda LA (1997) Molecular aspects of cannabinoid receptors. Crit Rev Neurobiol 11:143-166 [PubMed: 9209828]

24. Maresz K, Carrier EJ, Ponomarev ED, Hillard CJ, Dittel BN (2005) Modulation of the cannabinoid CB2 receptor in microglial cells in response to inflammatory stimuli. J Neurochem 95:437-445 [PubMed: 16086683]

25. Cabral GA, Marciano-Cabral F (2005) Cannabinoid receptors in microglia of the central nervous system: immune functional relevance. J Leukoc Biol 78:1192-1197 [PubMed: 16204639]

26. Herkenham M, Lynn AB, Johnson MR, Melvin LS, de Costa BR, Rice KC (1991) Characterization and localization of cannabinoid receptors in rat brain: a quantitative in vitro autoradiographic study. J Neurosci 11:563-583 [PubMed: 1992016]

27. Rinaldi-Carmona M, Barth F, Heaulme M, Shire D, Calandra B, Congy C, Martinez S, Maruani J, Neliat G, Caput D et al. (1994) SR141716A, a potent and selective antagonist of the brain cannabinoid receptor. FEBS Lett 350:240-244 [PubMed: 8070571]

28. Gueudet C, Santucci V, Rinaldi-Carmona M, Soubrie P, Le Fur G (1995) The CB1 cannabinoid receptor antagonist SR 141716A affects A9 dopamine neuronal activity in the rat. Neuroreport 6:1421-1425 [PubMed: 7488739]

29. French ED (1997) delta9-tetrahydrocannabinol excites rat VTA dopamine neurons through activation of cannabinoid CB1 but not opioid receptors. Neurosci Lett 226:159-162 [PubMed: 9175591]

30. Aceto MD, Scates SM, Lowe JA, Martin BR (1995) Cannabinoid precipitated withdrawal by the selective cannabinoid receptor antagonist, SR 141716A. Eur J Pharmacol 282:R1-R2 [PubMed: 7498260]

31. Tsou K, Patrick SL, Walker JM (1995) Physical withdrawal in rats tolerant to delta 9tetrahydrocannabinol precipitated by a cannabinoid receptor antagonist. Eur J Pharmacol 280:R13-R15 [PubMed: 8566091]

32. Aceto MD, Scates SM, Lowe JA, Martin BR (1996) Dependence on delta 9-tetrahydrocannabinol: studies on precipitated and abrupt withdrawal. J Pharmacol Exp Ther 278:1290-1295 [PubMed: 8819514]

33. Collins DR, Pertwee RG, Davies SN (1995) Prevention by the cannabinoid antagonist, SR141716A, of cannabinoid-mediated blockade of long-term potentiation in the rat hippocampal slice. Br J Pharmacol 115:869-870 [PubMed: 7582512]

34. Terranova JP, Michaud JC, Le Fur G, Soubrie P (1995) Inhibition of long-term potentiation in rat hippocampal slices by anandamide and WIN55212-2: reversal by SR141716 A, a selective antagonist of CB1 cannabinoid receptors. Naunyn Schmiedeberg's Arch Pharmacol 352:576-579 [PubMed: 8751088] 
35. Reche I, Fuentes JA, Ruiz-Gayo M (1996) A role for central cannabinoid and opioid systems in peripheral delta 9-tetrahydrocannabinol-induced analgesia in mice. Eur J Pharmacol 301:75-81 [PubMed: 8773449]

36. Richardson JD, Aanonsen L, Hargreaves KM (1997) SR 141716A, a cannabinoid receptor antagonist, produces hyperalgesia in untreated mice. Eur J Pharmacol 319:R3-R4 [PubMed: 9042616]

37. Herzberg U, Eliav E, Bennett GJ, Kopin IJ (1997) The analgesic effects of R(+)-WIN 55,212-2 mesylate, a high affinity cannabinoid agonist, in a rat model of neuropathic pain. Neurosci Lett 221:157-160 [PubMed: 9121688]

38. Christensen R, Kristensen PK, Bartels EM, Bliddal H, Astrup A (2007) Efficacy and safety of the weight-loss drug rimonabant: a meta-analysis of randomised trials. Lancet 370:1706-1713 [PubMed: 18022033]

39. Sam AH, Salem V, Ghatei MA (2011) Rimonabant: from RIO to ban. J Obes 2011:432607 [PubMed: 21773005]

40. Ashton JC, Glass M (2007) The cannabinoid CB2 receptor as a target for inflammation-dependent neurodegeneration. Curr Neuropharmacol 5:73-80 [PubMed: 18615177]

41. Katchan V, David P, Shoenfeld Y (2016) Cannabinoids and autoimmune diseases: a systematic review. Autoimmun Rev 15:513-528 [PubMed: 26876387]

42. Morales P, Goya P, Jagerovic N (2018) Emerging strategies targeting CB2 cannabinoid receptor: biased agonism and allosterism. Biochem Pharmacol 157:8-17 [PubMed: 30055149]

43. Soethoudt M, Grether U, Fingerle J, Grim TW, Fezza F, de Petrocellis L, Ullmer C, Rothenhausler B, Perret C, van Gils N, Finlay D, MacDonald C, Chicca A, Gens MD, Stuart J, de Vries H, Mastrangelo N, Xia L, Alachouzos G, Baggelaar MP, Martella A, Mock ED, Deng H, Heitman LH, Connor M, Di Marzo V, Gertsch J, Lichtman AH, Maccarrone M, Pacher P, Glass M, van der Stelt M (2017) Cannabinoid CB2 receptor ligand profiling reveals biased signalling and off-target activity. Nat Commun 8:13958 [PubMed: 28045021]

44. Devane WA, Hanus L, Breuer A, Pertwee RG, Stevenson LA, Griffin G, Gibson D, Mandelbaum A, Etinger A, Mechoulam R (1992) Isolation and structure of a brain constituent that binds to the cannabinoid receptor. Science 258:1946-1949 [PubMed: 1470919]

45. Sugiura T, Kondo S, Sukagawa A, Nakane S, Shinoda A, Itoh K, Yamashita A, Waku K (1995) 2Arachidonoylglycerol: a possible endogenous cannabinoid receptor ligand in brain. Biochem Biophys Res Commun 215:89-97 [PubMed: 7575630]

46. Mechoulam R, Ben-Shabat S, Hanus L, Ligumsky M, Kaminski NE, Schatz AR, Gopher A, Almog S, Martin BR, Compton DR et al. (1995) Identification of an endogenous 2-monoglyceride, present in canine gut, that binds to cannabinoid receptors. Biochem Pharmacol 50:83-90 [PubMed: 7605349]

47. Re G, Barbero R, Miolo A, Di Marzo V (2007) Palmitoylethanolamide, endocannabinoids and related cannabimimetic compounds in protection against tissue inflammation and pain: potential use in companion animals. Vet J 173:21-30 [PubMed: 16324856]

48. Rodriguez de Fonseca F, Navarro M, Gomez R, Escuredo L, Nava F, Fu J, Murillo-Rodriguez E, Giuffrida A, LoVerme J, Gaetani S, Kathuria S, Gall C, Piomelli D (2001) An anorexic lipid mediator regulated by feeding. Nature 414:209-212 [PubMed: 11700558]

49. Lambert DM, Di Marzo V (1999) The palmitoylethanolamide and oleamide enigmas: are these two fatty acid amides cannabimimetic? Curr Med Chem 6:757-773 [PubMed: 10469890]

50. Thabuis C, Tissot-Favre D, Bezelgues JB, Martin JC, Cruz-Hernandez C, Dionisi F, Destaillats F (2008) Biological functions and metabolism of oleoylethanolamide. Lipids 43:887-894 [PubMed: 18704536]

51. Hardison S, Weintraub ST, Giuffrida A (2006) Quantification of endocannabinoids in rat biological samples by GC/MS: technical and theoretical considerations. Prostaglandins Other Lipid Mediat 81:106-112 [PubMed: 17085319]

52. Richardson D, Ortori CA, Chapman V, Kendall DA, Barrett DA (2007) Quantitative profiling of endocannabinoids and related compounds in rat brain using liquid chromatography-tandem electrospray ionization mass spectrometry. Anal Biochem 360:216-226 [PubMed: 17141174] 
53. Kingsley PJ, Marnett LJ (2007) LC-MS-MS analysis of neutral eicosanoids. Methods Enzymol 433:91-112 [PubMed: 17954230]

54. Kingsley PJ, Marnett LJ (2009) Analysis of endocannabinoids, their congeners and COX-2 metabolites. J Chromatogr B Analyt Technol Biomed Life Sci 877:2746-2754

55. Buczynski MW, Parsons LH (2010) Quantification of brain endocannabinoid levels: methods, interpretations and pitfalls. Br J Pharmacol 160:423-442 [PubMed: 20590555]

56. Giuffrida A, Parsons LH, Kerr TM, Rodriguez de Fonseca F, Navarro M, Piomelli D (1999) Dopamine activation of endogenous cannabinoid signaling in dorsal striatum. Nat Neurosci 2:358363 [PubMed: 10204543]

57. Wiskerke J, Irimia C, Cravatt BF, De Vries TJ, Schoffelmeer AN, Pattij T, Parsons LH (2012) Characterization of the effects of reuptake and hydrolysis inhibition on interstitial endocannabinoid levels in the brain: an in vivo microdialysis study. ACS Chem Neurosci 3:407417 [PubMed: 22860210]

58. Ahn K, Johnson DS, Mileni M, Beidler D, Long JZ, McKinney MK, Weerapana E, Sadagopan N, Liimatta M, Smith SE, Lazerwith S, Stiff C, Kamtekar S, Bhattacharya K, Zhang Y, Swaney S, Van Becelaere K, Stevens RC, Cravatt BF (2009) Discovery and characterization of a highly selective FAAH inhibitor that reduces inflammatory pain. Chem Biol 16:411-420 [PubMed: 19389627]

59. Hsu KL, Tsuboi K, Adibekian A, Pugh H, Masuda K, Cravatt BF (2012) DAGLbeta inhibition perturbs a lipid network involved in macrophage inflammatory responses. Nat Chem Biol 8:9991007 [PubMed: 23103940]

60. Long JZ, Nomura DK, Cravatt BF (2009) Characterization of monoacylglycerol lipase inhibition reveals differences in central and peripheral endocannabinoid metabolism. Chem Biol 16:744-753 [PubMed: 19635411]

61. Ogasawara D, Deng H, Viader A, Baggelaar MP, Breman A, den Dulk H, van den Nieuwendijk AM, Soethoudt M, van der Wel T, Zhou J, Overkleeft HS, Sanchez-Alavez M, Mori S, Nguyen W, Conti B, Liu X, Chen Y, Liu QS, Cravatt BF, van der Stelt M (2016) Rapid and profound rewiring of brain lipid signaling networks by acute diacylglycerol lipase inhibition. Proc Natl Acad Sci U S A 113:26-33 [PubMed: 26668358]

62. Bachovchin DA, Cravatt BF (2012) The pharmacological landscape and therapeutic potential of serine hydrolases. Nat Rev Drug Discov 11:52-68 [PubMed: 22212679]

63. Rogers SL, Doody RS, Mohs RC, Friedhoff LT (1998) Donepezil improves cognition and global function in Alzheimer disease: a 15-week, double-blind, placebo-controlled study. Donepezil Study Group. Arch Intern Med 158:1021-1031 [PubMed: 9588436]

64. Duysen EG, Stribley JA, Fry DL, Hinrichs SH, Lockridge O (2002) Rescue of the acetylcholinesterase knockout mouse by feeding a liquid diet; phenotype of the adult acetylcholinesterase deficient mouse. Brain Res Dev Brain Res 137:43-54 [PubMed: 12128253]

65. Tuin AW, Mol MA, van den Berg RM, Fidder A, van der Marel GA, Overkleeft HS, Noort D (2009) Activity-based protein profiling reveals broad reactivity of the nerve agent sarin. Chem Res Toxicol 22:683-689 [PubMed: 19226147]

66. Schreiber SL, Kotz JD, Li M, Aube J, Austin CP, Reed JC, Rosen H, White EL, Sklar LA, Lindsley CW, Alexander BR, Bittker JA, Clemons PA, de Souza A, Foley MA, Palmer M, Shamji AF, Wawer MJ, McManus O, Wu M, Zou B, Yu H, Golden JE, Schoenen FJ, Simeonov A, Jadhav A, Jackson MR, Pinkerton AB, Chung TD, Griffin PR, Cravatt BF, Hodder PS, Roush WR, Roberts E, Chung DH, Jonsson CB, Noah JW, Severson WE, Ananthan S, Edwards B, Oprea TI, Conn PJ, Hopkins CR, Wood MR, Stauffer SR, Emmitte KA, Team NIHMLP (2015) Advancing biological understanding and therapeutics discovery with small-molecule probes. Cell 161:1252-1265 [PubMed: 26046436]

67. Liu Y, Patricelli MP, Cravatt BF (1999) Activity-based protein profiling: the serine hydrolases. Proc Natl Acad Sci U S A 96:14694-14699 [PubMed: 10611275]

68. Janssen FJ, Deng H, Baggelaar MP, Allara M, van der Wel T, den Dulk H, Ligresti A, van Esbroeck AC, McGuire R, Di Marzo V, Overkleeft HS, van der Stelt M (2014) Discovery of glycine sulfonamides as dual inhibitors of sn-1-diacylglycerol lipase alpha and alpha/betahydrolase domain 6. J Med Chem 57:6610-6622 [PubMed: 24988361] 
69. Baggelaar MP, Chameau PJ, Kantae V, Hummel J, Hsu KL, Janssen F, van der Wel T, Soethoudt M, Deng H, den Dulk H, Allara M, Florea BI, Di Marzo V, Wadman WJ, Kruse CG, Overkleeft HS, Hankemeier T, Werkman TR, Cravatt BF, van der Stelt M (2015) Highly selective, reversible inhibitor identified by comparative chemoproteomics modulates diacylglycerol lipase activity in neurons. J Am Chem Soc 137:8851-8857 [PubMed: 26083464]

70. Baggelaar MP, Van der Stelt M (2017) Competitive ABPP of serine hydrolases: a case study on DAGL-alpha. Methods Mol Biol 1491:161-169 [PubMed: 27778288]

71. van Rooden EJ, Florea BI, Deng H, Baggelaar MP, van Esbroeck ACM, Zhou J, Overkleeft HS, van der Stelt M (2018) Mapping in vivo target interaction profiles of covalent inhibitors using chemical proteomics with label-free quantification. Nat Protoc 13:752-767 [PubMed: 29565900]

72. Niphakis MJ, Cravatt BF (2014) Enzyme inhibitor discovery by activity-based protein profiling. Annu Rev Biochem 83:341-377 [PubMed: 24905785]

73. Johnson DS, Stiff C, Lazerwith SE, Kesten SR, Fay LK, Morris M, Beidler D, Liimatta MB, Smith SE, Dudley DT, Sadagopan N, Bhattachar SN, Kesten SJ, Nomanbhoy TK, Cravatt BF, Ahn K (2011) Discovery of PF-04457845: a highly potent, orally bioavailable, and selective urea FAAH inhibitor. ACS Med Chem Lett 2:91-96 [PubMed: 21666860]

74. Ahn K, Smith SE, Liimatta MB, Beidler D, Sadagopan N, Dudley DT, Young T, Wren P, Zhang Y, Swaney S, Van Becelaere K, Blankman JL, Nomura DK, Bhattachar SN, Stiff C, Nomanbhoy TK, Weerapana E, Johnson DS, Cravatt BF (2011) Mechanistic and pharmacological characterization of PF-04457845: a highly potent and selective fatty acid amide hydrolase inhibitor that reduces inflammatory and noninflammatory pain. J Pharmacol Exp Ther 338:114-124 [PubMed: 21505060]

75. Long JZ, Nomura DK, Vann RE, Walentiny DM, Booker L, Jin X, Burston JJ, Sim-Selley LJ, Lichtman AH, Wiley JL, Cravatt BF (2009) Dual blockade of FAAH and MAGL identifies behavioral processes regulated by endocannabinoid crosstalk in vivo. Proc Natl Acad Sci U S A 106:20270-20275 [PubMed: 19918051]

76. Cravatt BF, Giang DK, Mayfield SP, Boger DL, Lerner RA, Gilula NB (1996) Molecular characterization of an enzyme that degrades neuromodulatory fatty-acid amides. Nature 384:83-87 [PubMed: 8900284]

77. Giang DK, Cravatt BF (1997) Molecular characterization of human and mouse fatty acid amide hydrolases. Proc Natl Acad Sci U S A 94:2238-2242 [PubMed: 9122178]

78. Long JZ, LaCava M, Jin X, Cravatt BF (2011) An anatomical and temporal portrait of physiological substrates for fatty acid amide hydrolase. J Lipid Res 52:337-344 [PubMed: 21097653]

79. Doenni VM, Gray JM, Song CM, Patel S, Hill MN, Pittman QJ (2016) Deficient adolescent social behavior following early-life inflammation is ameliorated by augmentation of anandamide signaling. Brain Behav Immun 58:237-247 [PubMed: 27453335]

80. Natividad LA, Buczynski MW, Herman MA, Kirson D, Oleata CS, Irimia C, Polis I, Ciccocioppo R, Roberto M, Parsons LH (2017) Constitutive increases in amygdalar corticotropin-releasing factor and fatty acid amide hydrolase drive an anxious phenotype. Biol Psychiatry 82:500-510 [PubMed: 28209423]

81. Bedse G, Bluett RJ, Patrick TA, Romness NK, Gaulden AD, Kingsley PJ, Plath N, Marnett LJ, Patel S (2018) Therapeutic endocannabinoid augmentation for mood and anxiety disorders: comparative profiling of FAAH, MAGL and dual inhibitors. Transl Psychiatry 8:92 [PubMed: 29695817]

82. Gobbi G, Bambico FR, Mangieri R, Bortolato M, Campolongo P, Solinas M, Cassano T, Morgese MG, Debonnel G, Duranti A, Tontini A, Tarzia G, Mor M, Trezza V, Goldberg SR, Cuomo V, Piomelli D (2005) Antidepressant-like activity and modulation of brain monoaminergic transmission by blockade of anandamide hydrolysis. Proc Natl Acad Sci U S A 102:18620-18625 [PubMed: 16352709]

83. Naidu PS, Varvel SA, Ahn K, Cravatt BF, Martin BR, Lichtman AH (2007) Evaluation of fatty acid amide hydrolase inhibition in murine models of emotionality. Psychopharmacology 192:61-70 [PubMed: 17279376]

84. Fichna J, Salaga M, Stuart J, Saur D, Sobczak M, Zatorski H, Timmermans JP, Bradshaw HB, Ahn K, Storr MA (2014) Selective inhibition of FAAH produces antidiarrheal and antinociceptive 
effect mediated by endocannabinoids and cannabinoid-like fatty acid amides. Neurogastroenterol Motil 26:470-481 [PubMed: 24460851]

85. Salaga M, Mokrowiecka A, Zakrzewski PK, Cygankiewicz A, Leishman E, Sobczak M, Zatorski H, Malecka-Panas E, Kordek R, Storr M, Krajewska WM, Bradshaw HB, Fichna J (2014) Experimental colitis in mice is attenuated by changes in the levels of endocannabinoid metabolites induced by selective inhibition of fatty acid amide hydrolase (FAAH). J Crohns Colitis 8:9981009 [PubMed: 24530133]

86. Sakin YS, Dogrul A, Ilkaya F, Seyrek M, Ulas UH, Gulsen M, Bagci S (2015) The effect of FAAH, MAGL, and dual FAAH/MAGL inhibition on inflammatory and colorectal distension-induced visceral pain models in rodents. Neurogastroenterol Motil 27:936-944 [PubMed: 25869205]

87. Rock EM, Limebeer CL, Ward JM, Cohen A, Grove K, Niphakis MJ, Cravatt BF, Parker LA (2015) Interference with acute nausea and anticipatory nausea in rats by fatty acid amide hydrolase (FAAH) inhibition through a PPARalpha and CB1 receptor mechanism, respectively: a double dissociation. Psychopharmacology 232:3841-3848 [PubMed: 26297326]

88. Wasilewski A, Misicka A, Sacharczuk M, Fichna J (2017) Modulation of the endocannabinoid system by the fatty acid amide hydrolase, monoacylglycerol and diacylglycerol lipase inhibitors as an attractive target for secretory diarrhoea therapy. J Physiol Pharmacol 68:591-596 [PubMed: 29151076]

89. Cippitelli A, Cannella N, Braconi S, Duranti A, Tontini A, Bilbao A, Defonseca FR, Piomelli D, Ciccocioppo R (2008) Increase of brain endocannabinoid anandamide levels by FAAH inhibition and alcohol abuse behaviours in the rat. Psychopharmacology 198:449-460 [PubMed: 18446329]

90. Merritt LL, Martin BR, Walters C, Lichtman AH, Damaj MI (2008) The endogenous cannabinoid system modulates nicotine reward and dependence. J Pharmacol Exp Ther 326:483-492 [PubMed: 18451315]

91. Schlosburg JE, Carlson BL, Ramesh D, Abdullah RA, Long JZ, Cravatt BF, Lichtman AH (2009) Inhibitors of endocannabinoid-metabolizing enzymes reduce precipitated withdrawal responses in THC-dependent mice. AAPS J 11:342-352 [PubMed: 19430909]

92. Cippitelli A, Astarita G, Duranti A, Caprioli G, Ubaldi M, Stopponi S, Kallupi M, Sagratini G, Rodriguez de Fonseca F, Piomelli D, Ciccocioppo R (2011) Endocannabinoid regulation of acute and protracted nicotine withdrawal: effect of FAAH inhibition. PLoS One 6:e28142 [PubMed: 22140525]

93. Muldoon PP, Lichtman AH, Parsons LH, Damaj MI (2013) The role of fatty acid amide hydrolase inhibition in nicotine reward and dependence. Life Sci 92:458-462 [PubMed: 22705310]

94. Kinsey SG, Long JZ, Cravatt BF, Lichtman AH (2010) Fatty acid amide hydrolase and monoacylglycerol lipase inhibitors produce anti-allodynic effects in mice through distinct cannabinoid receptor mechanisms. J Pain 11:1420-1428 [PubMed: 20554481]

95. Booker L, Kinsey SG, Abdullah RA, Blankman JL, Long JZ, Ezzili C, Boger DL, Cravatt BF, Lichtman AH (2012) The fatty acid amide hydrolase (FAAH) inhibitor PF-3845 acts in the nervous system to reverse LPS-induced tactile allodynia in mice. Br J Pharmacol 165:2485-2496 [PubMed: 21506952]

96. Nasirinezhad F, Jergova S, Pearson JP, Sagen J (2015) Attenuation of persistent pain-related behavior by fatty acid amide hydrolase (FAAH) inhibitors in a rat model of HIV sensory neuropathy. Neuropharmacology 95:100-109 [PubMed: 25486617]

97. Bhuniya D, Kharul RK, Hajare A, Shaikh N, Bhosale S, Balwe S, Begum F, De S, Athavankar S, Joshi D, Madgula V, Joshi K, Raje AA, Meru AV, Magdum A, Mookhtiar KA, Barbhaiya R (2019) Discovery and evaluation of novel FAAH inhibitors in neuropathic pain model. Bioorg Med Chem Lett 29:238-243 [PubMed: 30503633]

98. D’Souza DC, Cortes-Briones J, Creatura G, Bluez G, Thurnauer H, Deaso E, Bielen K, Surti T, Radhakrishnan R, Gupta A, Gupta S, Cahill J, Sherif MA, Makriyannis A, Morgan PT, Ranganathan M, Skosnik PD (2019) Efficacy and safety of a fatty acid amide hydrolase inhibitor (PF-04457845) in the treatment of cannabis withdrawal and dependence in men: a double-blind, placebo-controlled, parallel group, phase 2a single-site randomised controlled trial. Lancet Psychiatry 6:35-45 [PubMed: 30528676]

99. Mayo LM, Asratian A, Linde J, Morena M, Haataja R, Hammar V, Augier G, Hill MN, Heilig M (2019) Elevated anandamide, enhanced recall of fear extinction, and attenuated stress responses 
following inhibition of fatty acid amide hydrolase: a randomized, controlled experimental medicine trial. Biol Psychiatry 87(6):538-547 [PubMed: 31590924]

100. Huggins JP, Smart TS, Langman S, Taylor L, Young T (2012) An efficient randomised, placebocontrolled clinical trial with the irreversible fatty acid amide hydrolase-1 inhibitor PF-04457845, which modulates endocannabinoids but fails to induce effective analgesia in patients with pain due to osteoarthritis of the knee. Pain 153:1837-1846 [PubMed: 22727500]

101. Wagenlehner FME, van Till JWO, Houbiers JGA, Martina RV, Cerneus DP, Melis J, Majek A, Vjaters E, Urban M, Ramonas H, Shoskes DA, Nickel JC (2017) Fatty acid amide hydrolase inhibitor treatment in men with chronic prostatitis/chronic pelvic pain syndrome: an adaptive double-blind, randomized controlled trial. Urology 103:191-197 [PubMed: 28254462]

102. Kerbrat A, Ferre JC, Fillatre P, Ronziere T, Vannier S, Carsin-Nicol B, Lavoue S, Verin M, Gauvrit JY, Le Tulzo Y, Edan G (2016) Acute neurologic disorder from an inhibitor of fatty acid amide hydrolase. N Engl J Med 375:1717-1725 [PubMed: 27806235]

103. Brosen K, Funck-Brentano C, Kroemer HK, Pirmohamed M, Schwab M (2017) Open letter on access to the BIA 10-2474 clinical trial data. Lancet 389:156

104. van Esbroeck ACM, Janssen APA, Cognetta AB 3rd, Ogasawara D, Shpak G, van der Kroeg M, Kantae V, Baggelaar MP, de Vrij FMS, Deng H, Allara M, Fezza F, Lin Z, van der Wel T, Soethoudt M, Mock ED, den Dulk H, Baak IL, Florea BI, Hendriks G, De Petrocellis L, Overkleeft HS, Hankemeier T, De Zeeuw CI, Di Marzo V, Maccarrone M, Cravatt BF, Kushner SA, van der Stelt M (2017) Activity-based protein profiling reveals off-target proteins of the FAAH inhibitor BIA 10-2474. Science 356:1084-1087 [PubMed: 28596366]

105. Huang Z, Ogasawara D, Seneviratne UI, Cognetta AB 3rd, Am Ende CW, Nason DM, Lapham K, Litchfield J, Johnson DS, Cravatt BF (2019) Global portrait of protein targets of metabolites of the neurotoxic compound BIA 10-2474. ACS Chem Biol 14:192-197 [PubMed: 30702848]

106. Hayes AW (2019) Commentary on BIA 10-2474. Regul Toxicol Pharmacol 104541

107. Li GL, Winter H, Arends R, Jay GW, Le V, Young T, Huggins JP (2012) Assessment of the pharmacology and tolerability of PF-04457845, an irreversible inhibitor of fatty acid amide hydrolase-1, in healthy subjects. Br J Clin Pharmacol 73:706-716 [PubMed: 22044402]

108. Pawsey S, Wood M, Browne H, Donaldson K, Christie M, Warrington S (2016) Safety, tolerability and pharmacokinetics of FAAH inhibitor V158866: a double-blind, randomised, placebo-controlled phase I study in healthy volunteers. Drugs R D 16:181-191 [PubMed: 26987975]

109. Postnov A, Schmidt ME, Pemberton DJ, de Hoon J, van Hecken A, van den Boer M, Zannikos P, van der Ark P, Palmer JA, Rassnick S, Celen S, Bormans G, van Laere K (2018) Fatty acid amide hydrolase inhibition by JNJ-42165279: a multiple-ascending dose and a positron emission tomography study in healthy volunteers. Clin Transl Sci 11:397-404 [PubMed: 29575526]

110. Di Marzo V (2012) Inhibitors of endocannabinoid breakdown for pain: not so FA(AH)cile, after all. Pain 153:1785-1786 [PubMed: 22785079]

111. Bryden LA, Nicholson JR, Doods H, Pekcec A (2015) Deficits in spontaneous burrowing behavior in the rat bilateral monosodium iodoacetate model of osteoarthritis: an objective measure of pain-related behavior and analgesic efficacy. Osteoarthr Cartil 23:1605-1612

112. Goparaju SK, Ueda N, Taniguchi K, Yamamoto S (1999) Enzymes of porcine brain hydrolyzing 2-arachidonoylglycerol, an endogenous ligand of cannabinoid receptors. Biochem Pharmacol 57:417-423 [PubMed: 9933030]

113. Dinh TP, Carpenter D, Leslie FM, Freund TF, Katona I, Sensi SL, Kathuria S, Piomelli D (2002) Brain monoglyceride lipase participating in endocannabinoid inactivation. Proc Natl Acad Sci U S A 99:10819-10824 [PubMed: 12136125]

114. Chanda PK, Gao Y, Mark L, Btesh J, Strassle BW, Lu P, Piesla MJ, Zhang MY, Bingham B, Uveges A, Kowal D, Garbe D, Kouranova EV, Ring RH, Bates B, Pangalos MN, Kennedy JD, Whiteside GT, Samad TA (2010) Monoacylglycerol lipase activity is a critical modulator of the tone and integrity of the endocannabinoid system. Mol Pharmacol 78:996-1003 [PubMed: 20855465] 
115. Pasquarelli N, Porazik C, Hanselmann J, Weydt P, Ferger B, Witting A (2015) Comparative biochemical characterization of the monoacylglycerol lipase inhibitor KML29 in brain, spinal cord, liver, spleen, fat and muscle tissue. Neuropharmacology 91:148-156 [PubMed: 25497453]

116. Taschler U, Eichmann TO, Radner FP, Grabner GF, Wolinski H, Storr M, Lass A, Schicho R, Zimmermann R (2015) Monoglyceride lipase deficiency causes desensitization of intestinal cannabinoid receptor type 1 and increased colonic mu-opioid receptor sensitivity. Br J Pharmacol 172:4419-4429 [PubMed: 26075589]

117. Petrenko AB, Yamazaki M, Sakimura K, Kano M, Baba H (2014) Augmented tonic pain-related behavior in knockout mice lacking monoacylglycerol lipase, a major degrading enzyme for the endocannabinoid 2-arachidonoylglycerol. Behav Brain Res 271:51-58 [PubMed: 24906199]

118. Kishimoto Y, Cagniard B, Yamazaki M, Nakayama J, Sakimura K, Kirino Y, Kano M (2015) Task-specific enhancement of hippocampus-dependent learning in mice deficient in monoacylglycerol lipase, the major hydrolyzing enzyme of the endocannabinoid 2arachidonoylglycerol. Front Behav Neurosci 9:134 [PubMed: 26082696]

119. Imperatore R, Morello G, Luongo L, Taschler U, Romano R, De Gregorio D, Belardo C, Maione S, Di Marzo V, Cristino L (2015) Genetic deletion of monoacylglycerol lipase leads to impaired cannabinoid receptor CB(1)R signaling and anxiety-like behavior. J Neurochem 135:799-813 [PubMed: 26223500]

120. Zhong P, Pan B, Gao XP, Blankman JL, Cravatt BF, Liu QS (2011) Genetic deletion of monoacylglycerol lipase alters endocannabinoid-mediated retrograde synaptic depression in the cerebellum. J Physiol 589:4847-4855 [PubMed: 21911610]

121. Pan B, Wang W, Zhong P, Blankman JL, Cravatt BF, Liu QS (2011) Alterations of endocannabinoid signaling, synaptic plasticity, learning, and memory in monoacylglycerol lipase knock-out mice. J Neurosci 31:13420-13430 [PubMed: 21940435]

122. Hohmann AG, Suplita RL, Bolton NM, Neely MH, Fegley D, Mangieri R, Krey JF, Walker JM, Holmes PV, Crystal JD, Duranti A, Tontini A, Mor M, Tarzia G, Piomelli D (2005) An endocannabinoid mechanism for stress-induced analgesia. Nature 435:1108-1112 [PubMed: 15973410]

123. Makara JK, Mor M, Fegley D, Szabo SI, Kathuria S, Astarita G, Duranti A, Tontini A, Tarzia G, Rivara S, Freund TF, Piomelli D (2005) Selective inhibition of 2-AG hydrolysis enhances endocannabinoid signaling in hippocampus. Nat Neurosci 8:1139-1141 [PubMed: 16116451]

124. Quistad GB, Klintenberg R, Caboni P, Liang SN, Casida JE (2006) Monoacylglycerol lipase inhibition by organophosphorus compounds leads to elevation of brain 2-arachidonoylglycerol and the associated hypomotility in mice. Toxicol Appl Pharmacol 211:78-83 [PubMed: 16310817]

125. Szabo B, Urbanski MJ, Bisogno T, Di Marzo V, Mendiguren A, Baer WU, Freiman I (2006) Depolarization-induced retrograde synaptic inhibition in the mouse cerebellar cortex is mediated by 2-arachidonoylglycerol. J Physiol 577:263-280 [PubMed: 16973696]

126. Hashimotodani Y, Ohno-Shosaku T, Kano M (2007) Presynaptic monoacylglycerol lipase activity determines basal endocannabinoid tone and terminates retrograde endocannabinoid signaling in the hippocampus. J Neurosci 27:1211-1219 [PubMed: 17267577]

127. Nomura DK, Hudak CS, Ward AM, Burston JJ, Issa RS, Fisher KJ, Abood ME, Wiley JL, Lichtman AH, Casida JE (2008) Monoacylglycerol lipase regulates 2-arachidonoylglycerol action and arachidonic acid levels. Bioorg Med Chem Lett 18:5875-5878 [PubMed: 18752948]

128. Long JZ, Li W, Booker L, Burston JJ, Kinsey SG, Schlosburg JE, Pavon FJ, Serrano AM, Selley DE, Parsons LH, Lichtman AH, Cravatt BF (2009) Selective blockade of 2-arachidonoylglycerol hydrolysis produces cannabinoid behavioral effects. Nat Chem Biol 5:37-44 [PubMed: 19029917]

129. Ramesh D, Ross GR, Schlosburg JE, Owens RA, Abdullah RA, Kinsey SG, Long JZ, Nomura DK, Sim-Selley LJ, Cravatt BF, Akbarali HI, Lichtman AH (2011) Blockade of endocannabinoid hydrolytic enzymes attenuates precipitated opioid withdrawal symptoms in mice. J Pharmacol Exp Ther 339:173-185 [PubMed: 21719468]

130. Muldoon PP, Chen J, Harenza JL, Abdullah RA, Sim-Selley LJ, Cravatt BF, Miles MF, Chen X, Lichtman AH, Damaj MI (2015) Inhibition of monoacylglycerol lipase reduces nicotine withdrawal. Br J Pharmacol 172:869-882 [PubMed: 25258021] 
131. Spradley JM, Guindon J, Hohmann AG (2010) Inhibitors of monoacylglycerol lipase, fatty-acid amide hydrolase and endocannabinoid transport differentially suppress capsaicin-induced behavioral sensitization through peripheral endocannabinoid mechanisms. Pharmacol Res 62:249-258 [PubMed: 20416378]

132. Khasabova IA, Chandiramani A, Harding-Rose C, Simone DA, Seybold VS (2011) Increasing 2arachidonoyl glycerol signaling in the periphery attenuates mechanical hyperalgesia in a model of bone cancer pain. Pharmacol Res 64:60-67 [PubMed: 21440630]

133. Woodhams SG, Wong A, Barrett DA, Bennett AJ, Chapman V, Alexander SP (2012) Spinal administration of the monoacylglycerol lipase inhibitor JZL184 produces robust inhibitory effects on nociceptive processing and the development of central sensitization in the rat. Br J Pharmacol 167:1609-1619 [PubMed: 22924700]

134. Kinsey SG, O’Neal ST, Long JZ, Cravatt BF, Lichtman AH (2011) Inhibition of endocannabinoid catabolic enzymes elicits anxiolytic-like effects in the marble burying assay. Pharmacol Biochem Behav 98:21-27 [PubMed: 21145341]

135. Sumislawski JJ, Ramikie TS, Patel S (2011) Reversible gating of endocannabinoid plasticity in the amygdala by chronic stress: a potential role for monoacylglycerol lipase inhibition in the prevention of stress-induced behavioral adaptation. Neuropsychopharmacology 36:2750-2761 [PubMed: 21849983]

136. Guindon J, Guijarro A, Piomelli D, Hohmann AG (2011) Peripheral antinociceptive effects of inhibitors of monoacylglycerol lipase in a rat model of inflammatory pain. Br J Pharmacol 163:1464-1478 [PubMed: 21198549]

137. Alhouayek M, Lambert DM, Delzenne NM, Cani PD, Muccioli GG (2011) Increasing endogenous 2-arachidonoylglycerol levels counteracts colitis and related systemic inflammation. FASEB J 25:2711-2721 [PubMed: 21551239]

138. Nomura DK, Morrison BE, Blankman JL, Long JZ, Kinsey SG, Marcondes MC, Ward AM, Hahn YK, Lichtman AH, Conti B, Cravatt BF (2011) Endocannabinoid hydrolysis generates brain prostaglandins that promote neuroinflammation. Science 334:809-813 [PubMed: 22021672]

139. Ye L, Zhang B, Seviour EG, Tao KX, Liu XH, Ling Y, Chen JY, Wang GB (2011) Monoacylglycerol lipase (MAGL) knockdown inhibits tumor cells growth in colorectal cancer. Cancer Lett 307:6-17 [PubMed: 21543155]

140. Zhang J, Liu Z, Lian Z, Liao R, Chen Y, Qin Y, Wang J, Jiang Q, Wang X, Gong J (2016) Monoacylglycerol lipase: a novel potential therapeutic target and prognostic Indicator for hepatocellular carcinoma. Sci Rep 6:35784 [PubMed: 27767105]

141. Xiang W, Shi R, Kang X, Zhang X, Chen P, Zhang L, Hou A, Wang R, Zhao Y, Zhao K, Liu Y, Ma Y, Luo H, Shang S, Zhang J, He F, Yu S, Gan L, Shi C, Li Y, Yang W, Liang H, Miao H (2018) Monoacylglycerol lipase regulates cannabinoid receptor 2-dependent macrophage activation and cancer progression. Nat Commun 9:2574 [PubMed: 29968710]

142. Kinsey SG, Nomura DK, O’Neal ST, Long JZ, Mahadevan A, Cravatt BF, Grider JR, Lichtman AH (2011) Inhibition of monoacylglycerol lipase attenuates nonsteroidal anti-inflammatory druginduced gastric hemorrhages in mice. J Pharmacol Exp Ther 338:795-802 [PubMed: 21659471]

143. Crowe MS, Kinsey SG (2017) MAGL inhibition modulates gastric secretion and motility following NSAID exposure in mice. Eur J Pharmacol 807:198-204 [PubMed: 28478068]

144. Chen R, Zhang J, Wu Y, Wang D, Feng G, Tang YP, Teng Z, Chen C (2012) Monoacylglycerol lipase is a therapeutic target for Alzheimer's disease. Cell Rep 2:1329-1339 [PubMed: 23122958]

145. Valdeolivas S, Pazos MR, Bisogno T, Piscitelli F, Iannotti FA, Allara M, Sagredo O, Di Marzo V, Fernandez-Ruiz J (2013) The inhibition of 2-arachidonoyl-glycerol (2-AG) biosynthesis, rather than enhancing striatal damage, protects striatal neurons from malonate-induced death: a potential role of cyclooxygenase-2-dependent metabolism of 2-AG. Cell Death Dis 4:e862 [PubMed: 24136226]

146. Nader J, Rapino C, Gennequin B, Chavant F, Francheteau M, Makriyannis A, Duranti A, Maccarrone M, Solinas M, Thiriet N (2014) Prior stimulation of the endocannabinoid system prevents methamphetamine-induced dopaminergic neurotoxicity in the striatum through activation of CB2 receptors. Neuropharmacology 87:214-221 [PubMed: 24709540] 
147. Fernandez-Suarez D, Celorrio M, Riezu-Boj JI, Ugarte A, Pacheco R, Gonzalez H, Oyarzabal J, Hillard CJ, Franco R, Aymerich MS (2014) Monoacylglycerol lipase inhibitor JZL184 is neuroprotective and alters glial cell phenotype in the chronic MPTP mouse model. Neurobiol Aging 35:2603-2616 [PubMed: 24973119]

148. Schlosburg JE, Blankman JL, Long JZ, Nomura DK, Pan B, Kinsey SG, Nguyen PT, Ramesh D, Booker L, Burston JJ, Thomas EA, Selley DE, Sim-Selley LJ, Liu QS, Lichtman AH, Cravatt BF (2010) Chronic monoacylglycerol lipase blockade causes functional antagonism of the endocannabinoid system. Nat Neurosci 13:1113-1119 [PubMed: 20729846]

149. Chang JW, Niphakis MJ, Lum KM, Cognetta AB 3rd, Wang C, Matthews ML, Niessen S, Buczynski MW, Parsons LH, Cravatt BF (2012) Highly selective inhibitors of monoacylglycerol lipase bearing a reactive group that is bioisosteric with endocannabinoid substrates. Chem Biol 19:579-588 [PubMed: 22542104]

150. Niphakis MJ, Cognetta AB 3rd, Chang JW, Buczynski MW, Parsons LH, Byrne F, Burston JJ, Chapman V, Cravatt BF (2013) Evaluation of NHS carbamates as a potent and selective class of endocannabinoid hydrolase inhibitors. ACS Chem Neurosci 4:1322-1332 [PubMed: 23731016]

151. Aaltonen N, Kedzierska E, Orzelska-Gorka J, Lehtonen M, Navia-Paldanius D, Jakupovic H, Savinainen JR, Nevalainen T, Laitinen JT, Parkkari T, Gynther M (2016) In vivo characterization of the ultrapotent monoacylglycerol lipase inhibitor $\{4$-[bis-(benzo[d][1,3]dioxol-5-yl)methyl]piperidin-1-yl $\}$ (1H-1,2,4-triazol-1-yl)m ethanone (JJKK-048). J Pharmacol Exp Ther 359:62-72 [PubMed: 27451409]

152. Granchi C, Lapillo M, Glasmacher S, Bononi G, Licari C, Poli G, El Boustani M, Caligiuri I, Rizzolio F, Gertsch J, Macchia M, Minutolo F, Tuccinardi T, Chicca A (2019) Optimization of a benzoylpiperidine class identifies a highly potent and selective reversible monoacylglycerol lipase (MAGL) inhibitor. J Med Chem 62:1932-1958 [PubMed: 30715876]

153. Cisar JS, Weber OD, Clapper JR, Blankman JL, Henry CL, Simon GM, Alexander JP, Jones TK, Ezekowitz RAB, O'Neill GP, Grice CA (2018) Identification of ABX-1431, a selective inhibitor of monoacylglycerol lipase and clinical candidate for treatment of neurological disorders. J Med Chem 61:9062-9084 [PubMed: 30067909]

154. Lotsch J, Oertel BG, Ultsch A (2014) Human models of pain for the prediction of clinical analgesia. Pain 155:2014-2021 [PubMed: 25020003]

155. McAllister LA, Butler CR, Mente S, O’Neil SV, Fonseca KR, Piro JR, Cianfrogna JA, Foley TL, Gilbert AM, Harris AR, Helal CJ, Johnson DS, Montgomery JI, Nason DM, Noell S, Pandit J, Rogers BN, Samad TA, Shaffer CL, da Silva RG, Uccello DP, Webb D, Brodney MA (2018) Discovery of Trifluoromethyl glycol Carbamates as potent and selective covalent monoacylglycerol lipase (MAGL) inhibitors for treatment of neuroinflammation. J Med Chem 61:3008-3026 [PubMed: 29498843]

156. Zhang L, Butler CR, Maresca KP, Takano A, Nag S, Jia Z, Arakawa R, Piro JR, Samad T, Smith DL, Nason DM, O’Neil S, McAllister L, Schildknegt K, Trapa P, McCarthy TJ, Villalobos A, Halldin C (2019) Identification and development of an irreversible monoacylglycerol lipase (MAGL) positron emission tomography (PET) radioligand with high specificity. J Med Chem 62:8532-8543 [PubMed: 31483137]

157. Aida J, Fushimi M, Kusumoto T, Sugiyama H, Arimura N, Ikeda S, Sasaki M, Sogabe S, Aoyama K, Koike T (2018) Design, synthesis, and evaluation of piperazinyl pyrrolidin-2-ones as a novel series of reversible monoacylglycerol lipase inhibitors. J Med Chem 61:9205-9217 [PubMed: 30251836]

158. Wyatt RM, Fraser I, Welty N, Lord B, Wennerholm M, Sutton SW, Ameriks MK, Dugovic C, Yun S, White A, Nguyen L, Koudriakova T, Tian G, Suarez J, Szewczuk L, Bonnette W, Ahn K, Ghosh B, Flores CM, Connolly PJ, Zhu B, Macielag MJ, Brandt MR, Chevalier K, Zhang SP, Lovenberg TW, Bonaventure P (2019) Pharmacologic characterization of JNJ-42226314, [1-(4fluorophenyl)indol-5-yl]-[3-[4-(thiazole-2-carbonyl)piperazin-1-yl]azetidin -1-yl] methanone, a reversible, selective and potent monoacylglycerol lipase inhibitor. J Pharmacol Exp Ther

159. Muccioli GG, Xu C, Odah E, Cudaback E, Cisneros JA, Lambert DM, Lopez Rodriguez ML, Bajjalieh S, Stella N (2007) Identification of a novel endocannabinoid-hydrolyzing enzyme expressed by microglial cells. J Neurosci 27:2883-2889 [PubMed: 17360910] 
160. Blankman JL, Simon GM, Cravatt BF (2007) A comprehensive profile of brain enzymes that hydrolyze the endocannabinoid 2-arachidonoylglycerol. Chem Biol 14:1347-1356 [PubMed: 18096503]

161. Marrs WR, Blankman JL, Horne EA, Thomazeau A, Lin YH, Coy J, Bodor AL, Muccioli GG, Hu SS, Woodruff G, Fung S, Lafourcade M, Alexander JP, Long JZ, Li W, Xu C, Moller T, Mackie K, Manzoni OJ, Cravatt BF, Stella N (2010) The serine hydrolase ABHD6 controls the accumulation and efficacy of 2-AG at cannabinoid receptors. Nat Neurosci 13:951-957 [PubMed: 20657592]

162. Buczynski MW, Herman MA, Hsu KL, Natividad LA, Irimia C, Polis IY, Pugh H, Chang JW, Niphakis MJ, Cravatt BF, Roberto M, Parsons LH (2016) Diacylglycerol lipase disinhibits VTA dopamine neurons during chronic nicotine exposure. Proc Natl Acad Sci U S A 113:1086-1091 [PubMed: 26755579]

163. Cao JK, Kaplan J, Stella N (2019) ABHD6: its place in endocannabinoid Signaling and beyond. Trends Pharmacol Sci 40:267-277 [PubMed: 30853109]

164. Thomas G, Betters JL, Lord CC, Brown AL, Marshall S, Ferguson D, Sawyer J, Davis MA, Melchior JT, Blume LC, Howlett AC, Ivanova PT, Milne SB, Myers DS, Mrak I, Leber V, Heier C, Taschler U, Blankman JL, Cravatt BF, Lee RG, Crooke RM, Graham MJ, Zimmermann R, Brown HA, Brown JM (2013) The serine hydrolase ABHD6 is a critical regulator of the metabolic syndrome. Cell Rep 5:508-520 [PubMed: 24095738]

165. Zhao S, Mugabo Y, Ballentine G, Attane C, Iglesias J, Poursharifi P, Zhang D, Nguyen TA, Erb H, Prentki R, Peyot ML, Joly E, Tobin S, Fulton S, Brown JM, Madiraju SR, Prentki M (2016) Alpha/beta-hydrolase domain 6 deletion induces adipose browning and prevents obesity and type 2 diabetes. Cell Rep 14:2872-2888 [PubMed: 26997277]

166. Grabner GF, Fawzy N, Pribasnig MA, Trieb M, Taschler U, Holzer M, Schweiger M, Wolinski H, Kolb D, Horvath A, Breinbauer R, Rulicke T, Rabl R, Lass A, Stadlbauer V, Hutter-Paier B, Stauber RE, Fickert P, Zechner R, Marsche G, Eichmann TO, Zimmermann R (2019) Metabolic disease and ABHD6 alter the circulating bis(monoacylglycerol) phosphate profile in mice and humans. J Lipid Res 60:1020-1031 [PubMed: 30894461]

167. Tchantchou F, Zhang Y (2013) Selective inhibition of alpha/beta-hydrolase domain 6 attenuates neurodegeneration, alleviates blood brain barrier breakdown, and improves functional recovery in a mouse model of traumatic brain injury. J Neurotrauma 30:565-579 [PubMed: 23151067]

168. Patel JZ, Nevalainen TJ, Savinainen JR, Adams Y, Laitinen T, Runyon RS, Vaara M, Ahenkorah S, Kaczor AA, Navia-Paldanius D, Gynther M, Aaltonen N, Joharapurkar AA, Jain MR, Haka AS, Maxfield FR, Laitinen JT, Parkkari T (2015) Optimization of 1,2,5-thiadiazole carbamates as potent and selective ABHD6 inhibitors. ChemMedChem 10:253-265 [PubMed: 25504894]

169. Naydenov AV, Horne EA, Cheah CS, Swinney K, Hsu KL, Cao JK, Marrs W, Blankman JL, Tu S, Cherry AE, Fung S, Wen A, Li W, Saporito MS, Selley DE, Cravatt BF, Oakley JC, Stella N (2014) ABHD6 blockade exerts antiepileptic activity in PTZ-induced seizures and in spontaneous seizures in R6/2 mice. Neuron 83:361-371 [PubMed: 25033180]

170. Zareie P, Sadegh M, Palizvan MR, Moradi-Chameh H (2018) Anticonvulsive effects of endocannabinoids; an investigation to determine the role of regulatory components of endocannabinoid metabolism in the pentylenetetrazol induced tonic- clonic seizures. Metab Brain Dis 33:939-948 [PubMed: 29504066]

171. Alhouayek M, Masquelier J, Cani PD, Lambert DM, Muccioli GG (2013) Implication of the antiinflammatory bioactive lipid prostaglandin D2-glycerol ester in the control of macrophage activation and inflammation by ABHD6. Proc Natl Acad Sci U S A 110:17558-17563 [PubMed: 24101490]

172. Wen J, Jones M, Tanaka M, Selvaraj P, Symes AJ, Cox B, Zhang Y (2018) WWL70 protects against chronic constriction injury-induced neuropathic pain in mice by cannabinoid receptorindependent mechanisms. J Neuroinflammation 15:9 [PubMed: 29310667]

173. Gruner BM, Schulze CJ, Yang D, Ogasawara D, Dix MM, Rogers ZN, Chuang CH, McFarland CD, Chiou SH, Brown JM, Cravatt BF, Bogyo M, Winslow MM (2016) An in vivo multiplexed small-molecule screening platform. Nat Methods 13:883-889 [PubMed: 27617390]

174. Manterola A, Bernal-Chico A, Cipriani R, Canedo-Antelo M, Moreno-Garcia A, Martin-Fontecha M, Perez-Cerda F, Sanchez-Gomez MV, Ortega-Gutierrez S, Brown JM, Hsu KL, Cravatt B, 
Matute C, Mato S (2018) Deregulation of the endocannabinoid system and therapeutic potential of ABHD6 blockade in the cuprizone model of demyelination. Biochem Pharmacol 157:189-201 [PubMed: 30075103]

175. Manterola A, Bernal-Chico A, Cipriani R, Ruiz A, Perez-Samartin A, Moreno-Rodriguez M, Hsu KL, Cravatt BF, Brown JM, Rodriguez-Puertas R, Matute C, Mato S (2018) Re-examining the potential of targeting ABHD6 in multiple sclerosis: efficacy of systemic and peripherally restricted inhibitors in experimental autoimmune encephalomyelitis. Neuropharmacology 141:181-191 [PubMed: 30171986]

176. Wen J, Ribeiro R, Tanaka M, Zhang Y (2015) Activation of CB2 receptor is required for the therapeutic effect of ABHD6 inhibition in experimental autoimmune encephalomyelitis. Neuropharmacology 99:196-209 [PubMed: 26189763]

177. Fisette A, Tobin S, Decarie-Spain L, Bouyakdan K, Peyot ML, Madiraju SRM, Prentki M, Fulton S, Alquier T (2016) Alpha/beta-hydrolase domain 6 in the ventromedial hypothalamus controls energy metabolism flexibility. Cell Rep 17:1217-1226 [PubMed: 27783937]

178. Blankman JL, Long JZ, Trauger SA, Siuzdak G, Cravatt BF (2013) ABHD12 controls brain lysophosphatidylserine pathways that are deregulated in a murine model of the neurodegenerative disease PHARC. Proc Natl Acad Sci U S A 110:1500-1505 [PubMed: 23297193]

179. Chen DH, Naydenov A, Blankman JL, Mefford HC, Davis M, Sul Y, Barloon AS, Bonkowski E, Wolff J, Matsushita M, Smith C, Cravatt BF, Mackie K, Raskind WH, Stella N, Bird TD (2013) Two novel mutations in ABHD12: expansion of the mutation spectrum in PHARC and assessment of their functional effects. Hum Mutat 34:1672-1678 [PubMed: 24027063]

180. Yoshimura H, Hashimoto T, Murata T, Fukushima K, Sugaya A, Nishio SY, Usami S (2015) Novel ABHD12 mutations in PHARC patients: the differential diagnosis of deaf-blindness. Ann Otol Rhinol Laryngol 124(Suppl 1):77S-83S [PubMed: 25743180]

181. Tingaud-Sequeira A, Raldua D, Lavie J, Mathieu G, Bordier M, Knoll-Gellida A, Rambeau P, Coupry I, Andre M, Malm E, Moller C, Andreasson S, Rendtorff ND, Tranebjaerg L, Koenig M, Lacombe D, Goizet C, Babin PJ (2017) Functional validation of ABHD12 mutations in the neurodegenerative disease PHARC. Neurobiol Dis 98:36-51 [PubMed: 27890673]

182. Frasquet M, Lupo V, Chumillas MJ, Vazquez-Costa JF, Espinos C, Sevilla T (2018) Phenotypical features of two patients diagnosed with PHARC syndrome and carriers of a new homozygous mutation in the ABHD12 gene. J Neurol Sci 387:134-138 [PubMed: 29571850]

183. Leishman E, Mackie K, Bradshaw HB (2019) Elevated levels of arachidonic acid-derived lipids including prostaglandins and endocannabinoids are present throughout ABHD12 knockout brains: novel insights into the neurodegenerative phenotype. Front Mol Neurosci 12:142 [PubMed: 31213981]

184. Ogasawara D, Ichu TA, Vartabedian VF, Benthuysen J, Jing H, Reed A, Ulanovskaya OA, Hulce JJ, Roberts A, Brown S, Rosen H, Teijaro JR, Cravatt BF (2018) Selective blockade of the lysoPS lipase ABHD12 stimulates immune responses in vivo. Nat Chem Biol 14:1099-1108 [PubMed: 30420694]

185. Kamat SS, Camara K, Parsons WH, Chen DH, Dix MM, Bird TD, Howell AR, Cravatt BF (2015) Immunomodulatory lysophosphatidylserines are regulated by ABHD16A and ABHD12 interplay. Nat Chem Biol 11:164-171 [PubMed: 25580854]

186. Joshi A, Shaikh M, Singh S, Rajendran A, Mhetre A, Kamat SS (2018) Biochemical characterization of the PHARC-associated serine hydrolase ABHD12 reveals its preference for very-long-chain lipids. J Biol Chem 293:16953-16963 [PubMed: 30237167]

187. Ogasawara D, Ichu TA, Jing H, Hulce JJ, Reed A, Ulanovskaya OA, Cravatt BF (2019) Discovery and optimization of selective and in vivo active inhibitors of the lysophosphatidylserine lipase alpha/beta-hydrolase domain-containing 12 (ABHD12). J Med Chem 62:1643-1656 [PubMed: 30720278]

188. Addy C, Wright H, Van Laere K, Gantz I, Erondu N, Musser BJ, Lu K, Yuan J, SanabriaBohorquez SM, Stoch A, Stevens C, Fong TM, De Lepeleire I, Cilissen C, Cote J, Rosko K, Gendrano IN 3rd, Nguyen AM, Gumbiner B, Rothenberg P, de Hoon J, Bormans G, Depre M, Eng WS, Ravussin E, Klein S, Blundell J, Herman GA, Burns HD, Hargreaves RJ, Wagner J, Gottesdiener K, Amatruda JM, Heymsfield SB (2008) The acyclic CB1R inverse agonist 
taranabant mediates weight loss by increasing energy expenditure and decreasing caloric intake. Cell Metab 7:68-78 [PubMed: 18177726]

189. Rosenstock J, Hollander P, Chevalier S, Iranmanesh A, S. S. Group (2008) SERENADE: the study evaluating rimonabant efficacy in drug-naive diabetic patients: effects of monotherapy with rimonabant, the first selective CB1 receptor antagonist, on glycemic control, body weight, and lipid profile in drug-naive type 2 diabetes. Diabetes Care 31:2169-2176 [PubMed: 18678611]

190. Rigotti NA, Gonzales D, Dale LC, Lawrence D, Chang Y, C. S. Group (2009) A randomized controlled trial of adding the nicotine patch to rimonabant for smoking cessation: efficacy, safety and weight gain. Addiction 104:266-276 [PubMed: 19149823]

191. Hollander PA, Amod A, Litwak LE, Chaudhari U, A. S. Group (2010) Effect of rimonabant on glycemic control in insulin-treated type 2 diabetes: the ARPEGGIO trial. Diabetes Care 33:605607 [PubMed: 20009090]

192. Proietto J, Rissanen A, Harp JB, Erondu N, Yu Q, Suryawanshi S, Jones ME, Johnson-Levonas AO, Heymsfield SB, Kaufman KD, Amatruda JM (2010) A clinical trial assessing the safety and efficacy of the CB1R inverse agonist taranabant in obese and overweight patients: low-dose study. Int J Obes 34:1243-1254

193. Sjostrom L, Rissanen A, Andersen T, Boldrin M, Golay A, Koppeschaar HP, Krempf M (1998) Randomised placebo-controlled trial of orlistat for weight loss and prevention of weight regain in obese patients. European Multicentre Orlistat Study Group. Lancet 352:167-172 [PubMed: 9683204]

194. Padwal RS, Majumdar SR (2007) Drug treatments for obesity: orlistat, sibutramine, and rimonabant. Lancet 369:71-77 [PubMed: 17208644]

195. Hoover HS, Blankman JL, Niessen S, Cravatt BF (2008) Selectivity of inhibitors of endocannabinoid biosynthesis evaluated by activity-based protein profiling. Bioorg Med Chem Lett 18:5838-5841 [PubMed: 18657971]

196. Bisogno T, Howell F, Williams G, Minassi A, Cascio MG, Ligresti A, Matias I, Schiano-Moriello A, Paul P, Williams EJ, Gangadharan U, Hobbs C, Di Marzo V, Doherty P (2003) Cloning of the first sn1-DAG lipases points to the spatial and temporal regulation of endocannabinoid signaling in the brain. J Cell Biol 163:463-468 [PubMed: 14610053]

197. Gao Y, Vasilyev DV, Goncalves MB, Howell FV, Hobbs C, Reisenberg M, Shen R, Zhang MY, Strassle BW, Lu P, Mark L, Piesla MJ, Deng K, Kouranova EV, Ring RH, Whiteside GT, Bates B, Walsh FS, Williams G, Pangalos MN, Samad TA, Doherty P (2010) Loss of retrograde endocannabinoid signaling and reduced adult neurogenesis in diacylglycerol lipase knock-out mice. J Neurosci 30:2017-2024 [PubMed: 20147530]

198. Tanimura A, Yamazaki M, Hashimotodani Y, Uchigashima M, Kawata S, Abe M, Kita Y, Hashimoto K, Shimizu T, Watanabe M, Sakimura K, Kano M (2010) The endocannabinoid 2arachidonoylglycerol produced by diacylglycerol lipase alpha mediates retrograde suppression of synaptic transmission. Neuron 65:320-327 [PubMed: 20159446]

199. Yoshida T, Fukaya M, Uchigashima M, Miura E, Kamiya H, Kano M, Watanabe M (2006) Localization of diacylglycerol lipase-alpha around postsynaptic spine suggests close proximity between production site of an endocannabinoid, 2-arachidonoyl-glycerol, and presynaptic cannabinoid CB1 receptor. J Neurosci 26:4740-4751 [PubMed: 16672646]

200. Katona I, Urban GM, Wallace M, Ledent C, Jung KM, Piomelli D, Mackie K, Freund TF (2006) Molecular composition of the endocannabinoid system at glutamatergic synapses. J Neurosci 26:5628-5637 [PubMed: 16723519]

201. Viader A, Ogasawara D, Joslyn CM, Sanchez-Alavez M, Mori S, Nguyen W, Conti B, Cravatt BF (2016) A chemical proteomic atlas of brain serine hydrolases identifies cell type-specific pathways regulating neuroinflammation. Elife 5:e12345 [PubMed: 26779719]

202. Powell DR, Gay JP, Wilganowski N, Doree D, Savelieva KV, Lanthorn TH, Read R, Vogel P, Hansen GM, Brommage R, Ding ZM, Desai U, Zambrowicz B (2015) Diacylglycerol lipase alpha knockout mice demonstrate metabolic and behavioral phenotypes similar to those of cannabinoid receptor 1 knockout mice. Front Endocrinol (Lausanne) 6:86 [PubMed: 26082754]

203. Shonesy BC, Bluett RJ, Ramikie TS, Baldi R, Hermanson DJ, Kingsley PJ, Marnett LJ, Winder DG, Colbran RJ, Patel S (2014) Genetic disruption of 2-arachidonoylglycerol synthesis reveals a 
key role for endocannabinoid signaling in anxiety modulation. Cell Rep 9:1644-1653 [PubMed: 25466252]

204. Jenniches I, Ternes S, Albayram O, Otte DM, Bach K, Bindila L, Michel K, Lutz B, Bilkei-Gorzo A, Zimmer A (2016) Anxiety, stress, and fear response in mice with reduced endocannabinoid levels. Biol Psychiatry 79:858-868 [PubMed: 25981172]

205. Begbie J, Doherty P, Graham A (2004) Cannabinoid receptor, CB1, expression follows neuronal differentiation in the early chick embryo. J Anat 205:213-218 [PubMed: 15379926]

206. Mulder J, Aguado T, Keimpema E, Barabas K, Ballester Rosado CJ, Nguyen L, Monory K, Marsicano G, Di Marzo V, Hurd YL, Guillemot F, Mackie K, Lutz B, Guzman M, Lu HC, GalveRoperh I, Harkany T (2008) Endocannabinoid signaling controls pyramidal cell specification and long-range axon patterning. Proc Natl Acad Sci U S A 105:8760-8765 [PubMed: 18562289]

207. Keimpema E, Barabas K, Morozov YM, Tortoriello G, Torii M, Cameron G, Yanagawa Y, Watanabe M, Mackie K, Harkany T (2010) Differential subcellular recruitment of monoacylglycerol lipase generates spatial specificity of 2-arachidonoyl glycerol signaling during axonal pathfinding. J Neurosci 30:13992-14007 [PubMed: 20962221]

208. Jung KM, Astarita G, Thongkham D, Piomelli D (2011) Diacylglycerol lipase-alpha and -beta control neurite outgrowth in neuro-2a cells through distinct molecular mechanisms. Mol Pharmacol 80:60-67 [PubMed: 21493725]

209. Jain T, Wager-Miller J, Mackie K, Straiker A (2013) Diacylglycerol lipasealpha (DAGLalpha) and DAGLbeta cooperatively regulate the production of 2-arachidonoyl glycerol in autaptic hippocampal neurons. Mol Pharmacol 84:296-302 [PubMed: 23748223]

210. Keimpema E, Alpar A, Howell F, Malenczyk K, Hobbs C, Hurd YL, Watanabe M, Sakimura K, Kano M, Doherty P, Harkany T (2013) Diacylglycerol lipase alpha manipulation reveals developmental roles for intercellular endocannabinoid signaling. Sci Rep 3:2093 [PubMed: 23806960]

211. Deng H, van der Stelt M (2018) Chemical tools to modulate 2-arachidonoylglycerol biosynthesis. Biotechnol Appl Biochem 65:9-15 [PubMed: 28589628]

212. Chevaleyre V, Castillo PE (2003) Heterosynaptic LTD of hippocampal GABAergic synapses: a novel role of endocannabinoids in regulating excitability. Neuron 38:461-472 [PubMed: 12741992]

213. Hashimotodani Y, Ohno-Shosaku T, Maejima T, Fukami K, Kano M (2008) Pharmacological evidence for the involvement of diacylglycerol lipase in depolarization-induced endocanabinoid release. Neuropharmacology 54:58-67 [PubMed: 17655882]

214. Williams EJ, Walsh FS, Doherty P (2003) The FGF receptor uses the endocannabinoid signaling system to couple to an axonal growth response. J Cell Biol 160:481-486 [PubMed: 12578907]

215. Goncalves MB, Suetterlin P, Yip P, Molina-Holgado F, Walker DJ, Oudin MJ, Zentar MP, Pollard S, Yanez-Munoz RJ, Williams G, Walsh FS, Pangalos MN, Doherty P (2008) A diacylglycerol lipase-CB2 cannabinoid pathway regulates adult subventricular zone neurogenesis in an agedependent manner. Mol Cell Neurosci 38:526-536 [PubMed: 18562209]

216. Oudin MJ, Gajendra S, Williams G, Hobbs C, Lalli G, Doherty P (2011) Endocannabinoids regulate the migration of subventricular zone-derived neuroblasts in the postnatal brain. $\mathrm{J}$ Neurosci 31:4000-4011 [PubMed: 21411643]

217. Gomez O, Arevalo-Martin A, Garcia-Ovejero D, Ortega-Gutierrez S, Cisneros JA, Almazan G, Sanchez-Rodriguez MA, Molina-Holgado F, Molina-Holgado E (2010) The constitutive production of the endocannabinoid 2-arachidonoylglycerol participates in oligodendrocyte differentiation. Glia 58:1913-1927 [PubMed: 20878765]

218. Yoshino H, Miyamae T, Hansen G, Zambrowicz B, Flynn M, Pedicord D, Blat Y, Westphal RS, Zaczek R, Lewis DA, Gonzalez-Burgos G (2011) Postsynaptic diacylglycerol lipase mediates retrograde endocannabinoid suppression of inhibition in mouse prefrontal cortex. J Physiol 589:4857-4884 [PubMed: 21807615]

219. Wu CS, Zhu J, Wager-Miller J, Wang S, O’Leary D, Monory K, Lutz B, Mackie K, Lu HC (2010) Requirement of cannabinoid $\mathrm{CB}(1)$ receptors in cortical pyramidal neurons for appropriate development of corticothalamic and thalamocortical projections. Eur J Neurosci 32:693-706 [PubMed: 21050275] 
220. Consortium GT (2013) The genotype-tissue expression (GTEx) project. Nat Genet 45:580-585 [PubMed: 23715323]

221. Zhou D, Zhang D, Sun X, Li Z, Ni Y, Shan Z, Li H, Liu C, Zhang S, Liu Y, Zheng R, Pan F, Zhu Y, Shi Y, Lai M (2018) A novel variant associated with HDL-C levels by modifying DAGLB expression levels: an annotation-based genome-wide association study. Eur J Hum Genet 26:838847 [PubMed: 29476167]

222. Shin M, Buckner A, Prince J, Bullock TNJ, Hsu KL (2019) Diacylglycerol lipase-beta is required for TNF-alpha response but not CD8(+) T cell priming capacity of dendritic cells. Cell Chem Biol 26(1036-1041):e1033

223. Jeong WI, Osei-Hyiaman D, Park O, Liu J, Batkai S, Mukhopadhyay P, Horiguchi N, HarveyWhite J, Marsicano G, Lutz B, Gao B, Kunos G (2008) Paracrine activation of hepatic CB1 receptors by stellate cell-derived endocannabinoids mediates alcoholic fatty liver. Cell Metab 7:227-235 [PubMed: 18316028]

224. Mulder J, Zilberter M, Pasquare SJ, Alpar A, Schulte G, Ferreira SG, Kofalvi A, Martin-Moreno AM, Keimpema E, Tanila H, Watanabe M, Mackie K, Hortobagyi T, de Ceballos ML, Harkany T (2011) Molecular reorganization of endocannabinoid signalling in Alzheimer's disease. Brain 134:1041-1060 [PubMed: 21459826]

225. Wilkerson JL, Ghosh S, Bagdas D, Mason BL, Crowe MS, Hsu KL, Wise LE, Kinsey SG, Damaj MI, Cravatt BF, Lichtman AH (2016) Diacylglycerol lipase beta inhibition reverses nociceptive behaviour in mouse models of inflammatory and neuropathic pain. Br J Pharmacol 173:16781692 [PubMed: 26915789]

226. Wilkerson JL, Donvito G, Grim TW, Abdullah RA, Ogasawara D, Cravatt BF, Lichtman AH (2017) Investigation of Diacylglycerol lipase alpha inhibition in the mouse lipopolysaccharide inflammatory pain model. J Pharmacol Exp Ther 363:394-401 [PubMed: 28970359]

227. Luk J, Lu Y, Ackermann A, Peng X, Bogdan D, Puopolo M, Komatsu DE, Tong S, Ojima I, Rebecchi MJ, Kaczocha M (2018) Contribution of diacylglycerol lipase beta to pain after surgery. J Pain Res 11:473-482 [PubMed: 29551907]

228. Shin M, Snyder HW, Donvito G, Schurman LD, Fox TE, Lichtman AH, Kester M, Hsu KL (2018) Liposomal delivery of diacylglycerol lipase-beta inhibitors to macrophages dramatically enhances selectivity and efficacy in vivo. Mol Pharm 15:721-728 [PubMed: 28901776]

229. Okamoto Y, Morishita J, Tsuboi K, Tonai T, Ueda N (2004) Molecular characterization of a phospholipase D generating anandamide and its congeners. J Biol Chem 279:5298-5305 [PubMed: 14634025]

230. Scott SA, Spencer CT, O’Reilly MC, Brown KA, Lavieri RR, Cho CH, Jung DI, Larock RC, Brown HA, Lindsley CW (2015) Discovery of desketoraloxifene analogues as inhibitors of mammalian, Pseudomonas aeruginosa, and NAPE phospholipase D enzymes. ACS Chem Biol 10:421-432 [PubMed: 25384256]

231. Leung D, Saghatelian A, Simon GM, Cravatt BF (2006) Inactivation of N-acyl phosphatidylethanolamine phospholipase D reveals multiple mechanisms for the biosynthesis of endocannabinoids. Biochemistry 45:4720-4726 [PubMed: 16605240]

232. Tsuboi K, Okamoto Y, Ikematsu N, Inoue M, Shimizu Y, Uyama T, Wang J, Deutsch DG, Burns MP, Ulloa NM, Tokumura A, Ueda N (2011) Enzymatic formation of N-acylethanolamines from $\mathrm{N}$-acylethanolamine plasmalogen through $\mathrm{N}$-acylphosphatidylethanolamine-hydrolyzing phospholipase D-dependent and -independent pathways. Biochim Biophys Acta 1811:565-577 [PubMed: 21801852]

233. Leishman E, Mackie K, Luquet S, Bradshaw HB (2016) Lipidomics profile of a NAPE-PLD KO mouse provides evidence of a broader role of this enzyme in lipid metabolism in the brain. Biochim Biophys Acta 1861:491-500 [PubMed: 26956082]

234. Geurts L, Everard A, Van Hul M, Essaghir A, Duparc T, Matamoros S, Plovier H, Castel J, Denis RG, Bergiers M, Druart C, Alhouayek M, Delzenne NM, Muccioli GG, Demoulin JB, Luquet S, Cani PD (2015) Adipose tissue NAPE-PLD controls fat mass development by altering the browning process and gut microbiota. Nat Commun 6:6495 [PubMed: 25757720]

235. Everard A, Plovier H, Rastelli M, Van Hul M, de Wouters d'Oplinter A, Geurts L, Druart C, Robine S, Delzenne NM, Muccioli GG, de Vos WM, Luquet S, Flamand N, Di Marzo V, Cani 
PD (2019) Intestinal epithelial N-acylphosphatidylethanolamine phospholipase D links dietary fat to metabolic adaptations in obesity and steatosis. Nat Commun 10:457 [PubMed: 30692526]

236. Overton HA, Fyfe MC, Reynet C (2008) GPR119, a novel G protein-coupled receptor target for the treatment of type 2 diabetes and obesity. Br J Pharmacol 153(Suppl 1):S76-S81 [PubMed: 18037923]

237. Fu J, Gaetani S, Oveisi F, Lo Verme J, Serrano A, Rodriguez De Fonseca F, Rosengarth A, Luecke H, Di Giacomo B, Tarzia G, Piomelli D (2003) Oleylethanolamide regulates feeding and body weight through activation of the nuclear receptor PPAR-alpha. Nature 425:90-93 [PubMed: 12955147]

238. Petersen G, Pedersen AH, Pickering DS, Begtrup M, Hansen HS (2009) Effect of synthetic and natural phospholipids on $\mathrm{N}$-acylphosphatidylethanolamine-hydrolyzing phospholipase D activity. Chem Phys Lipids 162:53-61 [PubMed: 19715685]

239. Castellani B, Diamanti E, Pizzirani D, Tardia P, Maccesi M, Realini N, Magotti P, Garau G, Bakkum T, Rivara S, Mor M, Piomelli D (2017) Synthesis and characterization of the first inhibitor of N-acylphosphatidylethanolamine phospholipase D (NAPE-PLD). Chem Commun (Camb) 53:12814-12817 [PubMed: 29143042]

240. Simon GM, Cravatt BF (2008) Anandamide biosynthesis catalyzed by the phosphodiesterase GDE1 and detection of glycerophospho-N-acyl ethanolamine precursors in mouse brain. J Biol Chem 283:9341-9349 [PubMed: 18227059]

241. Simon GM, Cravatt BF (2010) Characterization of mice lacking candidate N-acyl ethanolamine biosynthetic enzymes provides evidence for multiple pathways that contribute to endocannabinoid production in vivo. Mol BioSyst 6:1411-1418 [PubMed: 20393650]

242. Lee HC, Simon GM, Cravatt BF (2015) ABHD4 regulates multiple classes of N-acyl phospholipids in the mammalian central nervous system. Biochemistry 54:2539-2549 [PubMed: 25853435]

243. Liu J, Wang L, Harvey-White J, Osei-Hyiaman D, Razdan R, Gong Q, Chan AC, Zhou Z, Huang BX, Kim HY, Kunos G (2006) A biosynthetic pathway for anandamide. Proc Natl Acad Sci U S A 103:13345-13350 [PubMed: 16938887]

244. Liu J, Wang L, Harvey-White J, Huang BX, Kim HY, Luquet S, Palmiter RD, Krystal G, Rai R, Mahadevan A, Razdan RK, Kunos G (2008) Multiple pathways involved in the biosynthesis of anandamide. Neuropharmacology 54:1-7 [PubMed: 17631919]

245. Rosenberger TA, Villacreses NE, Contreras MA, Bonventre JV, Rapoport SI (2003) Brain lipid metabolism in the cPLA2 knockout mouse. J Lipid Res 44:109-117 [PubMed: 12518029]

246. Piro JR, Benjamin DI, Duerr JM, Pi Y, Gonzales C, Wood KM, Schwartz JW, Nomura DK, Samad TA (2012) A dysregulated endocannabinoid-eicosanoid network supports pathogenesis in a mouse model of Alzheimer's disease. Cell Rep 1:617-623 [PubMed: 22813736]

247. Pihlaja R, Takkinen J, Eskola O, Vasara J, Lopez-Picon FR, Haaparanta-Solin M, Rinne JO (2015) Monoacylglycerol lipase inhibitor JZL184 reduces neuroinflammatory response in APdE9 mice and in adult mouse glial cells. J Neuroinflammation 12:81 [PubMed: 25927213]

248. Yan W, Yun Y, Ku T, Li G, Sang N (2016) NO2 inhalation promotes Alzheimer's disease-like progression: cyclooxygenase-2-derived prostaglandin E2 modulation and monoacylglycerol lipase inhibition-targeted medication. Sci Rep 6:22429 [PubMed: 26928013]

249. Kita Y, Yoshida K, Tokuoka SM, Hamano F, Yamazaki M, Sakimura K, Kano M, Shimizu T (2015) Fever is mediated by conversion of endocannabinoid 2-arachidonoylglycerol to prostaglandin E2. PLoS One 10:e133663 [PubMed: 26196692]

250. Sanchez-Alavez M, Nguyen W, Mori S, Moroncini G, Viader A, Nomura DK, Cravatt BF, Conti B (2015) Monoacylglycerol lipase regulates fever response. PLoS One 10:e0134437 [PubMed: 26287872]

251. Urquhart P, Nicolaou A, Woodward DF (2015) Endocannabinoids and their oxygenation by cyclooxygenases, lipoxygenases and other oxygenases. Biochim Biophys Acta 1851:366-376 [PubMed: 25543004]

252. Davies NM (1998) Clinical pharmacokinetics of ibuprofen. The first 30 years. Clin Pharmacokinet 34:101-154 [PubMed: 9515184] 
253. Duggan KC, Hermanson DJ, Musee J, Prusakiewicz JJ, Scheib JL, Carter BD, Banerjee S, Oates JA, Marnett LJ (2011) (R)-Profens are substrate-selective inhibitors of endocannabinoid oxygenation by COX-2. Nat Chem Biol 7:803-809 [PubMed: 22053353]

254. Lotsch J, Geisslinger G, Mohammadian P, Brune K, Kobal G (1995) Effects of flurbiprofen enantiomers on pain-related chemo-somatosensory evoked potentials in human subjects. $\mathrm{Br} \mathrm{J}$ Clin Pharmacol 40:339-346 [PubMed: 8554936]

255. Bishay P, Schmidt H, Marian C, Haussler A, Wijnvoord N, Ziebell S, Metzner J, Koch M, Myrczek T, Bechmann I, Kuner R, Costigan M, Dehghani F, Geisslinger G, Tegeder I (2010) Rflurbiprofen reduces neuropathic pain in rodents by restoring endogenous cannabinoids. PLoS One 5:e10628 [PubMed: 20498712]

256. Hu SS, Bradshaw HB, Chen JS, Tan B, Walker JM (2008) Prostaglandin E2 glycerol ester, an endogenous COX-2 metabolite of 2-arachidonoylglycerol, induces hyperalgesia and modulates NFkappaB activity. Br J Pharmacol 153:1538-1549 [PubMed: 18297109]

257. Bruser A, Zimmermann A, Crews BC, Sliwoski G, Meiler J, Konig GM, Kostenis E, Lede V, Marnett LJ, Schoneberg T (2017) Prostaglandin E2 glyceryl ester is an endogenous agonist of the nucleotide receptor P2Y6. Sci Rep 7:2380 [PubMed: 28539604]

258. Alhouayek M, Buisseret B, Paquot A, Guillemot-Legris O, Muccioli GG (2018) The endogenous bioactive lipid prostaglandin D2-glycerol ester reduces murine colitis via DP1 and PPARgamma receptors. FASEB J 32:5000-5011 [PubMed: 29630407]

259. Elhassanny AEM, Ladin DA, Soliman E, Albassam H, Morris A, Kobet R, Thayne K, Burns C, Danell AS, Van Dross R (2019) Prostaglandin D2-ethanolamide induces skin cancer apoptosis by suppressing the activity of cellular antioxidants. Prostaglandins Other Lipid Mediat 142:9-23 [PubMed: 30858059]

260. Liang Y, Woodward DF, Guzman VM, Li C, Scott DF, Wang JW, Wheeler LA, Garst ME, Landsverk K, Sachs G, Krauss AH, Cornell C, Martos J, Pettit S, Fliri H (2008) Identification and pharmacological characterization of the prostaglandin FP receptor and FP receptor variant complexes. Br J Pharmacol 154:1079-1093 [PubMed: 18587449]

261. Woodward DF, Phelps RL, Krauss AH, Weber A, Short B, Chen J, Liang Y, Wheeler LA (2004) Bimatoprost: a novel antiglaucoma agent. Cardiovasc Drug Rev 22:103-120 [PubMed: 15179448]

262. Craven ER, Walters T, Christie WC, Day DG, Lewis RA, Goodkin ML, Chen M, Wangsadipura V, Robinson MR, Bejanian M, Bimatoprost SRSG (2019) 24-month phase I/II clinical trial of Bimatoprost sustained-release implant (Bimatoprost SR) in Glaucoma patients. Drugs

263. Jha AK, Sarkar R, Udayan UK, Roy PK, Jha AK, Chaudhary RKP (2018) Bimatoprost in dermatology. Indian Dermatol Online J 9:224-228 [PubMed: 29854658]

264. Gatta L, Piscitelli F, Giordano C, Boccella S, Lichtman A, Maione S, Di Marzo V (2012) Discovery of prostamide F2alpha and its role in inflammatory pain and dorsal horn nociceptive neuron hyperexcitability. PLoS One 7:e31111 [PubMed: 22363560] 